\title{
Exposure of in-pram babies to airborne particles during morning drop-in and afternoon pick-up of school children
}

\author{
Prashant Kumar $^{\mathrm{a}, \mathrm{b},{ }^{*}, \text { Ioar Rivas }}{ }^{\mathrm{a}}$, Lovish Sachdeva ${ }^{\mathrm{a}, \mathrm{c}}$
}

${ }^{a}$ Department of Civil and Environmental Engineering, Faculty of Engineering and Physical

Sciences, University of Surrey, Guildford GU2 7XH, United Kingdom

${ }^{\mathrm{b}}$ Environmental Flow (EnFlo) Research Centre, Faculty of Engineering and Physical

Sciences, University of Surrey, Guildford GU2 7XH, United Kingdom

${ }^{c}$ Department of Civil Engineering, Indian Institute of Technology Roorkee - 247 667,

Uttarakhand, India

\section{Graphical abstract}

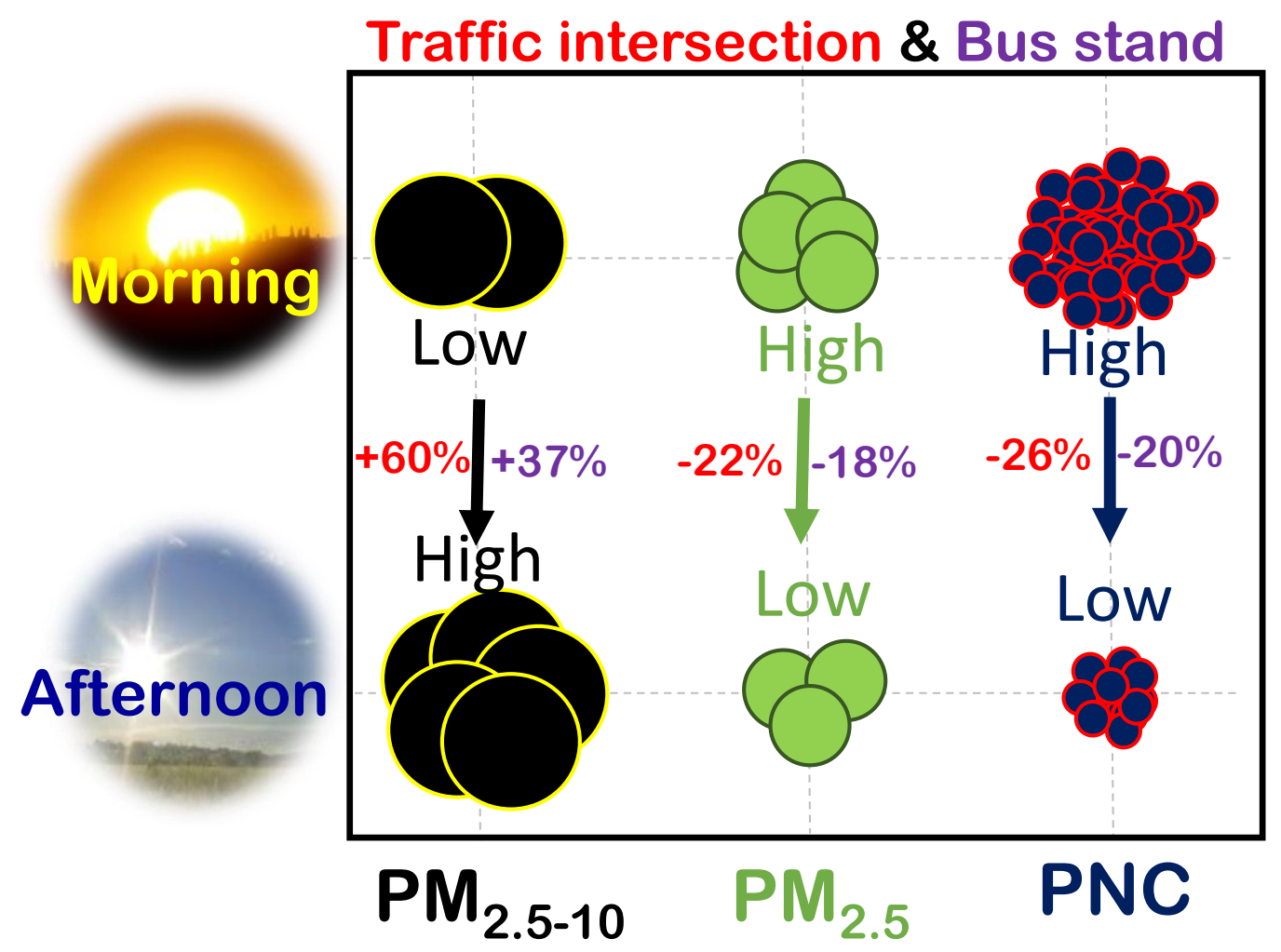

\section{Research highlights}

- $\quad \mathrm{PM}_{2.5}$ and $\mathrm{PM}_{2.5-10}$ particles dominated morning and afternoon hours, respectively

- Traffic intersections (TIs) and bus stand emerged as pollution hotspots

- PNC were by $\sim 65 \%$ higher at both TIs and bus stand than at the rest of the route

- Small differences in $\mathrm{PM}_{2.5}$ concentration between babies and adults were noted

Cite this article as: Kumar, P., Rivas, I., Sachdeva, L., 2017. Exposure of in-pram babies to airborne particles during morning drop-in and afternoon pick-up of school children. Environment Pollution, doi:10.1016/j.envpol.2017.02.021 


\begin{abstract}
In-pram babies are more susceptible to air pollution effects, yet studies assessing their exposure are limited. We measured size-resolved particle mass (PMC; 0.25-32 $\mu \mathrm{m}$ ) and number (PNC; $0.2-1 \mu \mathrm{m}$ ) concentrations on a $2.7 \mathrm{~km}$ route. The instruments were placed inside a baby pram. The route passed through 4 traffic intersections (TIs) and a bus stand. A total of $\sim 87 \mathrm{~km}$ road length was covered through 64 trips, made during school drop-in (morning) and pick-up (afternoon) hours. The objectives were to assess PMC and PNC exposure to in-pram babies at different route segments, understand their physicochemical characteristics and exposure differences between in-pram babies and adults carrying them. Over 5-fold variability (14.1$78.2 \mu \mathrm{g} \mathrm{m}^{-3}$ ) was observed in PMCs. Small-sized particles, including ultrafine particles, were always higher by $66 \%\left(\mathrm{PM}_{1}\right), 29 \%\left(\mathrm{PM}_{2.5}\right)$ and $31 \%$ (PNC) during the morning than afternoon. Coarse particles $\left(\mathrm{PM}_{2.5-10}\right)$ showed an opposite trend with $70 \%$ higher concentration during afternoon than morning. TIs emerged as pollution hotspots for all the particle types. For example, $\mathrm{PM}_{2.5}, \mathrm{PM}_{2.5-10}$ and PNCs during the morning (afternoon) at TIs were 7 (10)\%, 19 (10)\% and 68 (62)\% higher, respectively, compared with the rest of the route. Bus stand was also a section of enhanced exposure to $\mathrm{PNC}$ and $\mathrm{PM}_{2.5}$, although not so much for $\mathrm{PM}_{2.5-10}$. EDX analyses revealed $\mathrm{Cl}, \mathrm{Na}$ and $\mathrm{Fe}$ as dominant elements. Road salt might be a source of $\mathrm{NaCl}$ due to de-icing during the measurements while Fe contributed by non-exhaust emissions from brake abrasion. The respiratory deposition rates imitated the trend of PMC, with higher doses of coarse and fine particles during the afternoon and morning runs, respectively. Special protection measures during conveyance of in-pram babies, especially at pollution hotspots such as traffic intersections and bus stands, could help to limit their exposure.
\end{abstract}

\title{
Capsule
}

Exposure assessment of in-pram babies showed much higher fine and ultrafine particles at traffic intersections and bus stands during morning (drop-in) than afternoon (pick-up) hours.

\section{Keywords}

Children exposure; Baby pram; Particulate matter; Fine particles; Ultrafine particles

\section{Introduction}

The negative effects of air pollution exposure on the public health are clearly evident (Heal et al., 2012). A large number of epidemiological studies have associated the exposure to air pollutants to a wide range of respiratory and cardiovascular diseases (among others) and an increase in mortality (Atkinson et al., 2015). For example, Lim et al. (2012) quantified the global burden of disease and attributed 3.2 million premature deaths and $3.1 \%$ of global disability-adjusted life years to ambient particulate matter (PM).

Children are considered to be the population group that is most susceptible to environmental

Cite this article as: Kumar, P., Rivas, I., Sachdeva, L., 2017. Exposure of in-pram babies to airborne particles during morning drop-in and afternoon pick-up of school children. Environment Pollution, doi:10.1016/j.envpol.2017.02.021 
exposures, because of their immature and developing systems, higher inhalation rates and lower body weight with respect to adults (Ashmore and Dimitroulopoulou 2009; Goldman 1995; Peled 2011). Past studies reported the association of increased risk of respiratory diseases and infant mortality with the exposure to air pollutants (Landrigan and Etzel 2014). Some studies have also observed an association of early-life exposure (including the first year of life) to air pollutants with the childhood asthma (Deng et al., 2015; Clark et al., 2010), allergic rhinitis (Deng et al., 2016) and an impaired cognitive development (Basagaña et al., 2016; Sunyer et al., 2016). However, studies showing exposure levels of the infants to particle number (PNC) and mass (PMC) concentrations (Table 1) are still sparse and therefore considered as a part of our investigation in this work.

The urban environments are characterised by appreciable particle number and mass emissions from road traffic and the other anthropogenic sources (Kumar et al., 2016; Kumar et al., 2011; Kumar et al., 2015a). Traditionally, exposure to air pollutants has been assessed through fixedsite air quality monitoring stations measuring at the background or traffic hotspots (Goel and Kumar 2014), but these stations might not be representative of the actual air pollution exposure (Kumar et al., 2015b; Steinle et al., 2013). This is particularly true during commuting since this activity results in an increased exposure when compared to other daily activities and is characterised by a high exposure to time ratio (Buonanno et al., 2013a; Dons et al., 2011; Rivas et al., 2016, 2017), especially in high vehicle density areas (Goel and Kumar 2015a). The reasons for this intense exposure is the proximity to the source (with levels of most air pollutants being particularly high along the busy roads) and the peak concentrations being usually observed during the peak traffic hours (Al-Dabbous and Kumar 2014; Kaur et al., 2005; Morawska et al., 2008; Rivas et al., 2016; Zhu et al., 2002). Particularly high PNC are to be expected on the signalised traffic intersections (TI) due to delay and stop-start conditions of the road vehicles (Goel and Kumar 2015a, b).

Pollutant concentration may vary both horizontally and vertically across the city (Goel and Kumar 2016; Kumar et al., 2008c). Because of their height, children during commuting are relatively closer to the traffic emissions than adults since vehicle tailpipes are usually at a height around 30-60 $\mathrm{cm}$ above the ground level. Previous studies observed an exponential decrease with height in concentrations of particle numbers and gaseous pollutants (Goel and Kumar 2016; Kumar et al., 2008b; Kumar et al., 2008c; Vardoulakis et al., 2002). These studies build a generic understanding that much higher concentrations are expected close to the road and thus in the breathing zone of the children.

A few studies have reported exposure assessments at a different height within the first $2 \mathrm{~m}$ above the ground that might capture the differences between the children and adults (Table 1). For example, Buzzard et al. (2009) reported that short-term (1.5s, 2.5s) averaged maximum 
concentrations of PM at adult head height ( $\sim 1.65 \mathrm{~m}$ at the mouth level) were on average half of those observed at the corresponding height of an infant in a pram $(\sim 0.85 \mathrm{~m})$. Likewise, other studies showed PNCs to be about $10 \%$ higher at $0.55 \mathrm{~m}$ (pram height) than at $1.70 \mathrm{~m}$, which corresponds to an adult face height (Garcia-Algar et al., 2014). Another study by Burtscher and Schüepp (2012) observed 35\% higher concentrations of ultrafine particles in a bicycle trailer where a child was located compared with those observed at the breathing height of the bicycle driver. On the contrary, Galea et al. (2014) concluded that children in buggies are exposed to lower $\mathrm{PM}_{2.5}$ concentrations than the adults pushing the pram. The morphological and chemical composition of particles is of great importance since these parameters are determinants of the toxicity (De Vizcaya-Ruiz et al., 2006; Decan et al., 2016). Hence, health impairments and their degree might diverge among inhaled materials; although epidemiological studies are still scarce in assessing the effects of individual PM components (Bell 2012; Bilenko et al., 2015; Wyzga and Rohr 2015). Off-line samples can be analysed in the laboratory using microanalysis techniques such as Scanning Electron Microscopy (SEM) to determine morphology and energy dispersive X-ray spectroscopy (EDS) to characterise elemental composition, as used in several environmental studies (Azarmi et al., 2015; Chithra and Shiva Nagendra 2013; Moreno et al., 2015a; Mouzourides et al., 2015; Slezakova et al., 2011).

Besides a limited amount of literature on exposure of babies in the prams, the datasets used in these studies was very limited. Therefore, due to high vulnerability of children (and especially for babies during their first month and years), the assessment of exposure of babies to traffic emissions is of extreme importance and form part of the objectives of this work.

The objectives of this study are to assess exposure to PMC and PNC in various size ranges while travelling in their prams during the morning and afternoon school pick-up/drop-in times. In particular, we aim to (i) determine the concentrations measured inside the baby prams and identify the main pollution hotspots of air pollution, (ii) quantify the PM and UFP exposure and associated particles dose of the babies, (iii) assess the physicochemical characteristics of the particles inhaled by the babies, and (iv) compare the difference in exposures between the babies in the pram and the adult pushing it.

\section{Methodology}

\subsection{Site description}

The experiment was carried out on a fixed route starting from the University of Surrey to the Sandfield Primary School in the town centre of Guildford, UK (Figure 1). Most parents carry their babies when dropping-off (morning) and picking-up (afternoon) their school children. The route was selected within the school catchment area so that it is representative of a possible typical route. Only weekdays were considered for monitoring since no school activities take place during the weekend. A total of 64 one-sided runs, giving a total of 32 round trips (University of Surrey - Sandfield Primary School - University of Surrey), were made for 
personal exposure monitoring of in-pram babies; of which 17 runs took place in the morning (starting $0800 \mathrm{~h}$, local time) and 15 in the afternoon (starting at $1500 \mathrm{~h}$, local time). The total length of the route was $2.7 \mathrm{~km}$ and it took an average of $36.2 \pm 2.4 \mathrm{~min}$ to walk. The time spent on the route was similar during both the morning $(35.6 \pm 2.3 \mathrm{~min})$ and the afternoon $(36.9 \pm 2.3$ $\min$ ) runs.

The route was designed to cross the maximum number of TIs and a central bus stand in order to understand the spatial variability in personal exposure. The selected routed passed through the Guildford Bus Station and 5 signalised TIs (Figure 1). The area surrounding the University of Surrey has a low traffic density since none of the main streets passes across the campus. However, local buses frequently cross the campus which may lead to intermittent increments of air pollutants concentrations. The rest of the route goes through a high congested traffic zone. After leaving the University, the route goes on a parallel road to the train railways, passes in front of the Guildford main train station, through the bus station and across some residential area (Figure 1). The Sandfield Primary School is located on a busy street, and it was the final destination of the route.

\subsection{Instrumentation and data collection}

A GRIMM EDM 107 (GRIMM Technologies Inc.) aerosol spectrometer was used for measuring particles in the $0.25-32 \mu \mathrm{m}$ diameter range. The flow of the instrument was controlled by an internal pump and kept at $1.21 \mathrm{~min}^{-1}$. The instrument reported PM concentrations at a time resolution of $6 \mathrm{sec}$. It was calibrated just before the measurements and has been successfully deployed in our previous mobile measurements (Azarmi and Kumar 2016; Kumar and Goel 2016).

A P-Trak 8525 (TSI Inc.) was employed for measuring PNC in the $0.2-1 \mu \mathrm{m}$ size range. PTrak is not able to measure particles in the nucleation mode $(<20 \mathrm{~nm})$, what might lead to an underestimation of the actual PNC measured in our study (Mishra et al., 2012; Rivas et al., 2017). Actually, previous studies in urban environments (including street canyons) have shown that traffic emissions contribute importantly to the nucleation mode, with a peak below 0.02 $\mu \mathrm{m}$ (Gidhagen et al., 2005; Kumar et al., 2008a; Wehner et al., 2002).

A Dylos DC1700 (Dylos Corp.) particulate matter monitor was used for PNC measurements of small $(0.5-2.5 \mu \mathrm{m}$ in aerodynamic diameter) and large $(>2.5 \mu \mathrm{m})$ particles. It is a particle counter based on light-scattering technology (laser beam operating at $650 \mathrm{~nm}$ wavelength) that was initially developed for indoor air quality monitoring (Dylos 2016). The output of the Dylos is particle counts per cubic foot (28.38 lit) of air. The upper concentration limit has been found out by Semple et al. (2013) in chamber experiments to be 65,356 particles per 0.01 cubic foot (equivalent to approximately $1,000 \mu \mathrm{g} \mathrm{m}^{-3}$ for $\mathrm{PM}_{2.5}$ ), which is an unlikely concentration to be 
reached in a typical urban environment, except if being very close to a combustion source such as vehicle tailpipes (Kumar et al., 2009). Previous studies have evaluated the performance of the Dylos, both in indoor and outdoor environments, and indicated that the Dylos is able to accurately determine particle size and operate at a wide range of particle concentration while providing similar results to other available monitors (Northcross et al., 2013). However, Steinle et al. (2015) indicated that Dylos (as a low-cost air pollution monitor) is not aimed to deliver a precision similar to the reference monitors, but to offer an indication of exposure to PM.

The position of both the pram and the instruments was continuously recorded on a second basis (i.e. $1 \mathrm{~Hz}$ ) using a Global Positioning System (GPS; Garmin Oregon 550). The instruments were placed inside a baby pram to mimic the exposure that a baby would receive while being strolled in a pram. The instruments inside the pram were placed at a height of $0.7 \mathrm{~m}$ above the floor. The pram was always pushed in the sidewalk, within a varying distance from the road traffic (between 0.3 and $2 \mathrm{~m}$ distance, depending on the sidewalk width).

The Dylos was placed inside the pram for about one-quarter of total runs together with the GRIMM particle spectrometer in order to develop a correlation with their measured PMC in real-world operational conditions, as seen in Supplementary Information, SI, Figure S1; we then used this correlation to make Dylos data comparable to the GRIMM instrument for the rest of the runs at the adult height. From run 17 onwards, the Dylos was carried by the pushing adult in order to quantify the exposure of the adult pushing the baby and compare it with the exposure received by the baby in the pram. The Dylos was placed close to the adult breathing zone between 1.40 and $1.60 \mathrm{~m}$ by means of Velcro straps with the inlet looking at the front. A protective cover was placed over the buttons to prevent accidental switch-off of the instrument.

A total of 32 round mobile runs resulted in a $6 \mathrm{sec}$ averaged 22594 data points $(37.7 \mathrm{~h})$ for GRIMM, $1 \mathrm{sec}$ averaged 129583 data points (36.0h) for P-Trak, and $1 \mathrm{~min}$ averaged 22594 data points (10.6h) for the Dylos in the adult position.

\subsection{SEM and EDS analysis}

Total PM mass was collected on PTFE filters with a diameter of $47 \mathrm{~mm}$ and a nominal thickness of $\approx 1000 \mu \mathrm{g} \mathrm{cm}^{-2}$ using GRIMM 1.107. A total of 3 samples were collected, all of them corresponding to the same route but different days of collection as described in Table S1. A blank filter was also included in the analysis for setting up a reference case.

After carbon coating of the sample surface, particles from all samples were characterised using a JEOL SEM (model JSM-7100F, Japan) with a spatial resolution (depending on the sample) of $1.2 \mathrm{~nm}$ at $30 \mathrm{kV}$ and $3.0 \mathrm{~nm}$ at $1 \mathrm{kV}$. The JEOL SEM was equipped with EDS, thus being able of obtaining information on morphology and elemental composition (semi-quantitative analysis) of the particles collected on the filters. The analyses were carried out at the 
MicroStructural Studies Unit of the University of Surrey (UK). Samples were scanned with a high-energy beam $(5-15 \mathrm{kV})$ of electrons in a raster pattern.

\subsection{Exposure assessment}

The respiratory deposition dose (RDD) is the product of PMC, deposition fraction (DF) and ventilation rate (VR). The PMC depends only on the outside environment, the DF on particle characteristics (size in particular) and, finally, the VR depends on the age, sex and the activity a subject is performing. The DF varies according to the particle diameter and hence is usually not directly proportional to the mass concentration. The RDD is estimated according to Eq. (1), which is adapted from ICRP (1994) and has been used extensively in the literature (Azarmi and Kumar 2016; Goel and Kumar 2015a).

$$
\mathrm{RDD} \text { of } \mathrm{PM} \text { (fractions) }=\mathrm{VR}_{j} \times \mathrm{DF}_{i} \times \mathrm{PM}_{i}
$$

Where $\mathrm{VR}_{\mathrm{j}}$ is the ventilation rate for the $j^{\text {th }}$ individual; $\mathrm{DF}_{i}$ and $\mathrm{PM} i$ are the $\mathrm{DF}$ and $\mathrm{PMC}$ for each of the $i^{\text {th }} \mathrm{PM}$ fraction, respectively. DFs were calculated with the mass median diameter $\left(d_{\mathrm{p}}\right)$ of PM in various size ranges using the Eqs. (2) and (3) provided by (Hinds 1999):

$$
D F=I F\left(0.058+\frac{0.911}{1+\exp (4.77+1.485 \ln d p)}+\frac{0.943}{1+\exp (0.508-2.58 \ln d p)}\right)
$$

Where $I F$ is the inhalable fraction which is calculated using Eq. (3):

\section{Results and discussions}

$$
I F=1-0.5\left(1-\frac{1}{1+0.00076 d p^{2.8}}\right)
$$

\subsection{In-pram PMC during mobile measurements}

Figure 2 shows the different fractions of PMC during the morning and afternoon runs. A large variability of concentrations was observed between the runs, showing differences up to a factor of 7 between the runs averaged concentrations (Figures 2a-b, Table S2). Run averaged $\mathrm{PM}_{10}$ ranged from 14.1 to $78.2 \mu \mathrm{g} \mathrm{m}^{-3}$ during morning runs compared with 18.3 to $120 \mu \mathrm{g} \mathrm{m}^{-3}$ during afternoon runs (Figures $2 \mathrm{a}-\mathrm{b}$, Table $\mathrm{S} 2$ ).

The $t$-test was performed on the data to assess statistically significant differences. A run-wise average of on-road afternoon $\mathrm{PM}_{10}$ concentrations $\left(44.0 \pm 26.3 \mu \mathrm{g} \mathrm{m}^{-3}\right)$ was $16 \%$ higher than during the morning $\left(37.8 \pm 16.8 \mu \mathrm{g} \mathrm{m}^{-3}\right.$; significant $p$-value $<0.001$; Figure 2$)$. This difference was in the opposite direction and much more marked for $\mathrm{PM}_{2.5}$ and $\mathrm{PM}_{1}$, having 31 and $47 \%$ higher concentrations during the morning $\left(\mathrm{PM}_{2.5}=21.5 \pm 14.7 \mu \mathrm{g} \mathrm{m}^{-3}, \mathrm{PM}_{1}=15.4 \pm 15.7 \mu \mathrm{g} \mathrm{m}^{-}\right.$ ${ }^{3}, p$-value $<0.001$ in both cases) than in the afternoon runs $\left(\mathrm{PM}_{2.5}=16.4 \pm 11.8 \mu \mathrm{g} \mathrm{m}^{-3} ; \mathrm{PM}_{1}=\right.$ $10.5 \pm 10.7 \mu \mathrm{g} \mathrm{m}^{-3}$; Figure 2). This results in the $\mathrm{PM}_{2.5-10}$ being significantly higher $(70 \%)$ in afternoons $\left(27.6 \pm 17.6 \mu \mathrm{g} \mathrm{m}^{-3}\right)$ compared with morning runs $\left(16.3 \pm 8.5 \mu \mathrm{g} \mathrm{m}^{-3} ; p\right.$-value $<0.001)$. Coarse particles are mainly primary particles generated by mechanical processes (Heal et al., 2012) and vehicles can importantly contribute to this fraction by the resuspension of road dust and tyre and brake wear emissions (Amato et al., 2009a; Kumar et al., 2013). On the other side, exhaust emissions contribute more importantly to the fine fraction (Viana et al.,

Cite this article as: Kumar, P., Rivas, I., Sachdeva, L., 2017. Exposure of in-pram babies to airborne particles during morning drop-in and afternoon pick-up of school children. Environment Pollution, doi:10.1016/j.envpol.2017.02.021 
2008). The lower concentration of coarse particles during the morning runs might be due to the moisture content of the pavement during early morning (owing to the overnight condensation of water due to cold temperatures), which drops the mobility and resuspension of road dust (Amato et al., 2012; Omstedt et al., 2005). Although having a higher traffic intensity during the morning, re-suspension was kept to a minimum owing to the settling of particles because of the wetness of the pavement from the overnight dew. Therefore, higher resuspension of coarser particles was observed during the afternoon when drier road conditions persisted. However, fresh exhaust emissions are responsible for the higher PMC in the fine fraction during the morning runs. This resulted in about 10\% higher total PMCs during the afternoon runs. In fact, this also explains the much higher proportion of the coarse fraction to the total PMC during the afternoon $(63 \%)$ than during the morning $(43 \%)$ runs.

A handful of literature is available on exposure to in-pram babies (Table 1). One study on this topic is of Galea et al. (2014) who measured $\mathrm{PM}_{2.5}$ measurements in the city of Edinburgh (UK). They performed 6 runs in each of their three selected routes obtaining a range of geometric mean $(\mathrm{GM})$ between 5.9 and $46.6 \mu \mathrm{g} \mathrm{m}^{-3}$, which is similar to the range between 4.8 and $63.5 \mu \mathrm{g} \mathrm{m}^{-3}$ of GM that we obtained.

\subsection{Effect of pollution hotspots on enhanced PMC exposure to babies}

In order to understand the spatial variability of coarse and fine particles at different parts of the route, Figure 3 shows the spatial variation of $\mathrm{PM}_{2.5-10}$ (corresponding to the afternoon run \#12 up) and $\mathrm{PM}_{2.5}$ (morning run \#25 down). Run \#12 up and \#25 down were selected because their corresponding average PMC ( $\mathrm{PM}_{2.5-10}$ in \#12 up as $21.8 \mu \mathrm{g} \mathrm{m}^{-3}$ and $\mathrm{PM}_{2.5}$ in run \#25 down as $19.3 \mu \mathrm{g} \mathrm{m}^{-3}$; Table S2) that were closest to the overall average concentrations (21.6 and $19.1 \mu^{-3} \mathrm{~g} \mathrm{~m}^{-3}$, respectively). High concentrations were observed at different points of the route, owing to traffic congestion and the surrounding built-up environment. However, high concentrations were consistently observed next to TIs (Figure 3) which has also been reported in previous studies involving pedestrians (Kumar and Goel 2016; Moreno et al., 2015b).

Figure 4 shows the concentrations at different sections of the route: TIs, bus stand and rest of the route (i.e., excluding TIs and bus stand) During the morning runs, the average concentration of $\mathrm{PM}_{2.5-10}$ and $\mathrm{PM}_{2.5}$ at TIs $\left(18.8 \pm 12.2\right.$ and $\left.22.5 \pm 15.9 \mu \mathrm{g} \mathrm{m}^{-3}\right)$ were 19 and $7 \%$ significantly higher than at the rest of the route ( $p$-value $<0.001$ from the $t$-test in both cases), which had corresponding values as $\mathrm{PM}_{2.5}\left(\right.$ and $\mathrm{PM}_{2.5-10}$ ) as $21.0 \pm 14.3(15.8 \pm 7.9) \mu \mathrm{g} \mathrm{m}^{-3}$, respectively (Table S3). In the afternoons at TIs, $\mathrm{PM}_{2.5-10}\left(30.1 \pm 17.2 \mu \mathrm{g} \mathrm{m}^{-3}\right)$ and $\mathrm{PM}_{2.5}\left(17.5 \pm 12.3 \mu \mathrm{g} \mathrm{m}^{-3}\right)$ were both by about $10 \%$ higher than the corresponding values $\left(27.5 \pm 18.1\right.$ and $16.0 \pm 11.8 \mu \mathrm{g} \mathrm{m}^{-}$ ${ }^{3}$; $p$-values for PM2.5 and $\mathrm{PM}_{2.5-10}$ were $<0.001$ and 0.03 , respectively) at the rest of the route. Therefore, concentrations of both coarse and fine particles were slightly higher at the TIs

Cite this article as: Kumar, P., Rivas, I., Sachdeva, L., 2017. Exposure of in-pram babies to airborne particles during morning drop-in and afternoon pick-up of school children. Environment Pollution, doi:10.1016/j.envpol.2017.02.021 
compared with the rest of the route (Figure 4). These higher concentrations can be explained due to abrupt changes in driving conditions (e.g., braking, acceleration/deceleration), temporary accumulation of vehicles (Kim et al., 2013; Kumar and Goel 2016) and an increase in fuel consumption due to the acceleration of vehicles (Goel and Kumar 2015a).

Taking a deeper look into PMCs around the TIs, we can observe the highest average concentrations at $\mathrm{TI}_{1}$ and $\mathrm{TI}_{2}$ (boxplots in Figure $\mathrm{S} 2$, values in Table $\mathrm{S} 3$ ). $\mathrm{TI}_{1}$ is surrounded by buildings that greatly limit the dispersion of pollutants (Ai and Mak 2015; Weber et al., 2006) while $\mathrm{TI}_{2}$ is the busiest intersection in the route but located in a more open area that favours the dispersion. This explains why $\mathrm{TI}_{1}$ has $11 \%$ higher concentrations for $\mathrm{PM}_{2.5}$ than the rest of TIs and showing usually higher concentrations than $\mathrm{TI}_{2}$. Generally, TIs also followed the overall trend in which respective concentrations of $\mathrm{PM}_{2.5}$ are relatively higher during the morning than the afternoon but an opposite trend was seen for $\mathrm{PM}_{2.5-10}$ for the similar reasons discussed in Section 3.1.

At the bus stand, coarse particles were by about $5 \%\left(15.0 \pm 9.0 \mu \mathrm{g} \mathrm{m}^{-3}\right)$ and $25 \%$ lower than the rest of the route during the morning (no significant differences, $p$-value $=0.36$ ) and afternoon (significant differences, $p$-value $<0.001$ ) hours, respectively. On the other hand, fine particles were by about $12 \%\left(23.5 \pm 13.7 \mu \mathrm{g} \mathrm{m}^{-3}\right)$ and $21 \%$ significantly higher than the rest of the route during the morning ( $p$-value $=0.027$ ) and afternoon $(p$-value $=0.013$ ) hours, respectively. The higher concentrations of fine particles can be explained from exhaust emissions by the running engines of idling buses when passengers get on and off the buses (Figure 4a). Conversely, these stationary idling buses limit the re-suspension of coarse particles explaining their lower concentrations at the bus stands (Figure 4b).

\subsection{In-pram PNC during mobile measurements}

Figure 5 shows the average PNC for the morning and afternoon trips. The run-wise average PNC was $10155 \pm 6030 \mathrm{~cm}^{-3}$ and $7739 \pm 5004 \mathrm{~cm}^{-3}$ during the morning and afternoon runs, respectively (Figure 5a-b). The average PNC was $31 \%$ significantly higher during the morning than afternoon runs ( $p$-value $<0.001$ ), similar to what was observed for $\mathrm{PM}_{2.5}$. These results were the expected since the traffic emissions are an important source of ultrafine particles (Kumar et al., 2014; Morawska et al., 2008) and the highest traffic intensities took place during the morning runs. The average PNCs inside the baby pram were much lower than those reported by roadside measurements in different cities of the UK (Agus et al., 2007; Kumar et al., 2014; Longley et al., 2003; Reche et al., 2011; von Bismarck-Osten et al., 2013), although these studies included smaller particles in their measured PNCs. Since traffic emissions substantially contribute to the nucleation mode particles, especially below $20 \mathrm{~nm}$ (Gidhagen et al., 2005; Kumar et al., 2008a; Wehner et al., 2002), an underestimation from the P-Trak is expected because of its detection limit being $20 \mathrm{~nm}$. Garcia-Algar et al. (2015; Table 1) also measured PNC concentrations in the same range (with P-Trak) in different roadside 
routes in a baby pram in the city of Barcelona, obtaining an average PNC of $48198 \pm 25296 \mathrm{~cm}^{-}$

${ }^{3}$. Their value is about 5-times higher than the average PNCs we measured in Guildford. This difference can be explained by the higher background PNC found in Barcelona than in other UK cities which are busier than Guildford (Kumar et al., 2014) and also that their routes were entirely monitored in street canyons characterised by heavy traffic.

Following the methodology used in Section 3.2, we plotted the run (\#24 down) that has the trip average PNC closest to the overall average of all runs for assessing the spatial variability (Figure 6). A large variability in average concentrations was noted, showing up to a factor of 8 during the morning $\left(2965-23014 \mathrm{~cm}^{-3}\right)$ and a factor of 14 during the afternoon (1819-25079 $\mathrm{cm}^{-3}$ ). PNC at the route section within the University campus were low because of low traffic volume. Thereafter the concentrations started to increase to high levels when approaching the city centre. PNC was found to be consistently higher near the traffic intersection and bus stand compared with the rest of the route (Figure 6d). For example, PNC at TIs during the morning $\left(14908 \pm 8982 \mathrm{~cm}^{-3}\right)$ and afternoon $\left(11031 \pm 6683 \mathrm{~cm}^{-3}\right)$ runs were $68 \%$ and $62 \%$ significantly higher than the corresponding values at the rest of the route $\left(8890 \pm 5682 \mathrm{~cm}^{-3}\right.$ and $6813 \pm 4850$ $\mathrm{cm}^{-3} ; p$-value $<0.001$ in both cases; Table 2). As previously observed for $\mathrm{PM}_{2.5}$ in Section 3.2 (Figure S3), $\mathrm{TI}_{1}$ showed the highest concentration among the rest of TIs (around $50 \%$ higher) owing to the higher vehicle density in this section of the route and the hindered dispersion by the surrounding buildings. Regarding the influence of the bus stand, PNCs were also much higher in this route section. In line with the $\mathrm{PM}_{2.5}$ (Section 3.2), PNC during the morning $\left(14396 \pm 9690 \mathrm{~cm}^{-3}\right)$ and the afternoon $\left(11534 \pm 6809 \mathrm{~cm}^{-3}\right)$ were 62 and $69 \%$ significantly higher at the bus stand than at the rest of the route ( $p$-value $<0.001$ in both cases), respectively, maintain their reputation as zones of high pollution exposure (Goel and Kumar 2014, 2015b).

\subsection{Comparison of babies and adult exposure}

We measured $\mathrm{PM}_{2.5}$ concentrations at adult heights to compare with those measured simultaneously inside the baby pram (Figure S4). A huge variability in mean concentration was noted during the morning $\left(9.6-36.3 \mu \mathrm{g} \mathrm{m}^{-3}\right)$ and afternoon $\left(9.1-19.6 \mu \mathrm{g} \mathrm{m}^{-3}\right)$ runs for babies. The corresponding range was comparatively smaller for adults during the morning (9.6-46.1 $\left.\mu \mathrm{g} \mathrm{m}^{-3}\right)$ and afternoon runs $\left(8.3-16.7 \mu \mathrm{g}-\mathrm{m}^{-3}\right)$. The mean concentration for overall runs was found out to be nearly identical for babies $\left(16.4 \pm 9.3 \mu \mathrm{g} \mathrm{m}^{-3}\right)$ and adults $\left(16.9 \pm 10.6 \mu \mathrm{g} \mathrm{m}^{-3}, p\right.$ value $=0.102$ ). However, $\mathrm{PM}_{2.5}$ concentrations for babies were about $5 \%$ significantly lower than adults during the morning ( $p$-value $=0.016$ ) runs as opposed to $10 \%$ higher for babies during the afternoon runs ( $p$-value $<0.001)$. Although a different instrument was used for adults and babies, the correlation between them was fairly good $\left(R^{2}=0.94\right.$; Figure $\left.\mathrm{S} 1\right)$. We can only compare these results to another study assessing $\mathrm{PM}_{2.5}$ concentrations in a baby pram (Galea et al., 2014). Their results indicate that adults were exposed to higher concentrations than babies. However, their monitoring was limited to only 6 days; they obtained the opposite result (i.e., 
babies exposed to higher concentrations) on one of their six days of monitoring. More longterm studies could further help to establish an exposure gradient between the in-pram babies and adults.

Further inspection of the data for the different parts of the route (Figures 9c-d) showed the mean $\mathrm{PM}_{2.5}$ concentration for babies was 5.0 (significant, $p$-value <0.045), 6.0 (not significantly different, $p$-value $<0.290$ ) and $5.7 \%$ (not significantly different, $p$-value $<0.515$ ) lower than adults during the morning hours for the rest of the route, traffic intersection and bus stand sections, respectively. For example, average $\mathrm{PM}_{2.5}$ during morning hours were 17.2 \pm 9.8 $\mu \mathrm{g} \mathrm{m}^{-3}$ (rest of route), $17.6 \pm 8.7 \mu \mathrm{g} \mathrm{m}^{-3}$ (traffic intersection) and $19.4 \pm 16.5 \mu \mathrm{g} \mathrm{m}^{-3}$ (bus stand) for babies compared with $18.1 \pm 11.4 \mu \mathrm{g} \mathrm{m}^{-3}$ (rest of the route), $18.6 \pm 12.3 \mu \mathrm{g} \mathrm{m}^{-3}$ (traffic intersection) and $20.5 \pm 10.1 \mathrm{\mu g} \mathrm{m}^{-3}$ (bus stand) for adults. The trend changed during the afternoon hours when the mean $\mathrm{PM}_{2.5}$ concentrations for babies were 12.5 (significant, $p$-value $<0.001$ ), 1 (not significantly different, $p$-value <0.724) and 7.7\% (not significantly different, $p$-value $<0.508)$ higher during the rest of the route $\left(13.2 \pm 5.6 \mu \mathrm{g} \mathrm{m}^{-3}\right)$, traffic intersections $\left(14.0 \pm 5.5 \mu \mathrm{g} \mathrm{m}^{-3}\right)$ and bus stand $\left(14.0 \pm 4.7 \mu \mathrm{g}-\mathrm{m}^{-3}\right)$, respectively, compared with the adults experiencing $11.7 \pm 3.8 \mu \mathrm{g} \mathrm{m}^{-3}, 13.8 \pm 3.1 \mu \mathrm{g} \mathrm{m}^{-3}$ and $13.0 \pm 3.2 \mu \mathrm{g}-\mathrm{m}^{-3}$ during the rest of the route, traffic intersections and bus stand, respectively. While our results indicate relatively higher exposure to $\mathrm{PM}_{2.5}$ to babies during the afternoon runs and lower during the morning hours, past studies also show similar kind of mixed results. For example, Galea et al. (2014) compared the $\mathrm{PM}_{2.5}$ concentrations inside a baby pram and at the adult height at 3 different routes over the 6 days of measurements. They generally observed higher exposures of the adults for most days when adult to baby ratios varied between 1.10 and 1.76. They observed an exception on one day when an opposite trend was seen, with an adult to baby ratios being between 0.84 and 0.87 ; no particular reason for this reversed trend was provided.

Exploring the differences between babies and adults at the different TIs (Table S4) showed no consistent results; sometimes higher exposures for babies than for adults and vice-versa, with most of the TI showing a difference $<5 \%$ (and always no statistically significant differences). For example, adult to baby ratios at the TIs ranged from $0.97-1.18$ during the morning, which changed to $0.88-1.14$ during the afternoon. This is expected given that the first few meter height of the TIs is highly affected by the traffic-induced turbulence due to stop-start, acceleration/deceleration conditions (Di Sabatino et al., 2003; Kumar et al., 2008a) and so is the case with the varied emissions and their dispersion (Goel and Kumar 2014, 2015a) contributing to the observed trend.

\subsection{Physicochemical properties of the particles}

The morphology and the chemical composition was characterised using SEM (Figure 7) and EDS techniques (Table S5). These analyses were performed on the bulk mass of total 
PM collected on 3 different filter samples (Table S1). The particles show a wide range of morphologies under the SEM, from agglomerates (related to vehicle exhaust emissions), crustal forms (related to mineral components), as well as the presence of some fibres, probably coming from the fabric of the pram (Figure 7). As expected, the EDS analysis of the blank PTFE filters showed the filter composition, being $88.9 \mathrm{wt} \%$ fluorine (F) and $10.8 \mathrm{wt} \%$ carbon (C); Table S5. Analysis through SEM-EDS are semi-quantitative, and only the relative contribution of each element was quantified for a specific section of the filter. In Samples 1 and 3, the dominant elements are chlorine $(\mathrm{Cl})$, sodium $(\mathrm{Na})$, iron $(\mathrm{Fe})$, and oxygen $(\mathrm{O})$; excluding $\mathrm{F}$ and $\mathrm{C}$ that are affected by the filter composition. Road salt can be considered an important contributor to PM in form of sodium chloride ( $\mathrm{NaCl}$, characterised by a crystal form) since the measurements were carried out in the winter time when salt is commonly used for de-icing or anti-icing of the roads, especially in the early morning. Fe is a typical crustal element, which is usually found in the form of iron oxides $\left(\mathrm{Fe}_{2} \mathrm{O}_{3}\right)$. However, its higher proportion with respect to other crustal elements ( $\mathrm{Si}, \mathrm{Al}, \mathrm{Mg}$ ) suggests a clear contribution from road traffic, being $\mathrm{Fe}$ a tracer of nonexhaust emissions from brake abrasion and commonly found in city dust profiles (Amato et al., 2009b). In Sample 3, the EDS analysis also revealed the presence of $\mathrm{Cu}$ in a low wt\% (Table S5), which is also a tracer for brake wear (Thorpe and Harrison 2008). Sample 3 corresponds to the sample with the highest bulk mass, mainly due to a higher number of runs, and therefore $\mathrm{Cu}$ might have become detectable for the EDS.

\subsection{Exposure assessment}

The RDD provides the net influx of the PM into the respiratory system and is often cited as the most important factor in determining the ability to adversely affecting the human body. The deposition fraction varies according to the particle diameter and therefore is usually not directly proportional to the mass concentration. We estimated the RDD of different PM fractions for male and female babies during morning and afternoon runs in different parts of the route (Figure 8). As stated in Section 2.5, the RDD is a product of mass concentration, DF and VR (Eq. 1). The former two depends only on the outside environment whereas the ventilation rate depends on the age, sex and the activity, a person is performing. The ventilation rate for the male and female babies of age ( $<1$ year) in sedentary condition is taken as 3.18 and 3.00 lit $\mathrm{min}^{-1}$ (US EPA 2009). Since the outside environment is same for both male and female babies during the calculation, the ratio of RDD of the male to the female babies will be fixed as 1.06 at any particular location during any period of the day. Therefore, we only discussed the results for female babies in the subsequent text and the RDD for male babies can be obtained by multiplying the above-noted factor for female babies.

The total RDD rates, which is a sum of fine and coarse particles, for female babies were found to vary substantially from run to run (Figure 8), within a range of 1.2-11.6 $\mu \mathrm{g} \mathrm{h}^{-1}$ and 3.0-20.4 $\mu \mathrm{g} \mathrm{h}{ }^{-1}$ during the morning and afternoon runs, respectively. The separation of the data 
suggested showed around $41 \%$ lower average RDD for coarse particles during morning runs $\left(2.8 \pm 1.4 \mu \mathrm{g} \mathrm{h}^{-1}\right)$ compared with afternoon runs $\left(4.7 \pm 2.9 \mu \mathrm{g} \mathrm{h}^{-1}\right.$; significant, $p$-value $\left.<0.001\right)$. The corresponding difference reduced to $10 \%$ for fine particles, with $1.1 \pm 0.6 \mu \mathrm{g} \mathrm{h}^{-1}$ during morning compared with $1.0 \pm 0.6 \mu \mathrm{g} \mathrm{h}^{-1}$ during the afternoon (significant, $p$-value $<0.001$ ). This effect was also reflected in the fraction of RDD that changed from $72 \%$ (morning) to $83 \%$ (afternoon) for coarse particles and from 28\% (morning) to 17\% (afternoon) for fine particles (Figure 8). The RDD rates mimic the trend of PMC. The abundance of fine particles during the morning hours was expected due to higher vehicle density, as discussed in Section 3.1. Moreover, the wetness of road pavement due to overnight dew and the higher relatively humidity during the morning $(84.9 \pm 6.5 \%)$ compared with afternoon $(71.4 \pm 12.5 \%)$ might have contributed to limit the re-suspension of coarse particles during morning runs, as also reported by previous studies (Kumar and Goel 2016). The studies quantifying the RDD for babies are scarce for direct comparison. We used a study that estimated RDD for walking along the urban roadsides to put our results in perspective. For example, Nyhan et al., (2014) determined the RDD for 8 adult pedestrians in Dublin and obtained an RDD of $27.6 \mu \mathrm{g} \mathrm{h}^{-1}$ for $\mathrm{PM}_{2.5}$ and 40.8 $\mu \mathrm{g} \mathrm{h}^{-1}$ for $\mathrm{PM}_{10}$, which are much higher than the ones we obtained for in-pram babies. Various factors might explain these differences. Firstly, our average concentrations were lower (overall $\left.\mathrm{PM}_{2.5}=19.1 \mu \mathrm{g} \mathrm{m}^{-3} ; \mathrm{PM}_{10}=40.7 \mu \mathrm{g} \mathrm{m}^{-3}\right)$ than theirs $\left(\mathrm{PM}_{2.5}=28.2 \mu \mathrm{g} \mathrm{m}^{-3} ; \mathrm{PM}_{10}=45.8 \mu \mathrm{g} \mathrm{m}^{-}\right.$ $\left.{ }^{3}\right)$. Secondly, a major effect might be due to the different inhalation rates, which depend on age and intensity of physical activity. The pedestrians assessed by Nyhan et al. (2014) were adults undergoing a moderate exercise (walking) while the in-pram babies were considered in resting position. The ventilation rate for a male adult (30-40 years old) is $30.30 \mathrm{lit} \mathrm{min}^{-1}$ compared with 3.08 lit $\min ^{-1}$ for a baby in a sedentary condition (sedentary condition; <1 yr) (US EPA 2009), giving an order of magnitude difference and explaining the low RDD in our case for inpram babies.

In order to assess the spatial variability in the exposure doses over the route, we further analysed the data by dividing our route into traffic intersections, bus stand, rest of the route, and overall route average. As expected, the RDD rates were found to be the highest at the TIs (Figure S5). For example, the mean RDD for coarse particles at the TIs during the morning runs $\left(3.2 \pm 2.1 \mu \mathrm{g} \mathrm{h}^{-1}\right)$ were about twice of those during the afternoon runs $\left(5.1 \pm 2.9 \mu \mathrm{g} \mathrm{h}^{-1}\right)$, demonstrating the dominance of coarse particles during the afternoon runs (significant, $p$-value $<0.001)$. The similar trend was evident for bus stand during the morning $\left(2.6 \pm 1.5 \mu \mathrm{g} \mathrm{h}^{-1}\right)$ and afternoon $\left(3.5 \pm 1.8 \mu \mathrm{g} \mathrm{h}^{-1}\right)$ runs (significant, $p$-value $\left.<0.001\right)$. However, the mean RDD for fine particles showed a reverse trend, as was seen for the PMCs (Section 3.1), with 1.2 $\pm 0.6 \mu \mathrm{g} \mathrm{h}^{-1}$ and $1.0 \pm 0.6 \mu \mathrm{g} \mathrm{h}^{-1}$ at TIs (significant, $p$-value $<0.001$ ) and $1.3 \pm 1.0 \mu \mathrm{g} \mathrm{h}^{-1}$ and $1.2 \pm 0.9 \mu \mathrm{g} \mathrm{h}^{-1}$ at the bus stands (not significantly different, $p$-value $<0.269$ ) during the morning and afternoon runs, respectively. An important finding is that in-pram babies experience relatively larger doses of fine particles during the morning while the doses are higher for coarse particles during

Cite this article as: Kumar, P., Rivas, I., Sachdeva, L., 2017. Exposure of in-pram babies to airborne particles during morning drop-in and afternoon pick-up of school children. Environment Pollution, doi:10.1016/j.envpol.2017.02.021 
the afternoon runs. Fine particles show larger health impacts compared to their larger counterparts (Heal et al., 2012) and at the young age children are more susceptible to particulate pollution due to their immature system, higher inhalation rates and lower body weight (Heinrich and Slama 2007), suggesting a clear need for precautionary measures to limit their exposure during their transport along the busy roadsides.

\section{Conclusions}

Personal exposure of in-pram babies for both PMC and PNC were assessed along with the concurrent measurements of adult exposure to $\mathrm{PM}_{2.5}$. The objectives were to quantify the in-pram babies exposure of airborne particles when the parents drop-in and pick-up their children during morning and afternoon hours. The specific contribution of traffic intersections, bus stand was also studied.

The following conclusions were drawn:

- $\quad \mathrm{PM}_{2.5}, \mathrm{PM}_{1}$ and PNC concentrations were 47, 31 and $31 \%$ higher during the morning runs than those during the afternoon hours, reflecting the influence of traffic emissions during the morning peak hours. Conversely, coarse particles were $70 \%$ higher in the afternoons, indicating that re-suspension was importantly affected by the wetness of road pavement due to overnight dew in the early mornings. A similar trend was reflected by the fraction composition showing the proportion of coarse particles as $43 \%$ and $63 \%$ during morning and afternoon runs, respectively.

- TIs were hotspots of enhanced exposure for $\mathrm{PM}_{2.5-10}$ (19 and 10\% higher during morning and afternoon, respectively), $\mathrm{PM}_{2.5}$ (7 and 10\% higher) and PNC concentrations (68\% and $62 \%$ higher) compared with the rest of the route. $\mathrm{TI}_{1}$ showed the highest $\mathrm{PM}_{2.5}$ and $\mathrm{PNC}$ concentrations since it was one of the busiest TIs on the route and the pollutant dispersion here may have been limited by the surrounding buildings. The section crossing the bus stand also showed higher concentrations for $\mathrm{PM}_{2.5}$ (12 and 21\% higher during morning and afternoon, respectively) and for PNC (62 and 69\%) compared with the rest of the route due to the fresh emissions of idling buses, but were lower for $\mathrm{PM}_{2.5-10}$ (5 and 25\% lower during morning and afternoon, respectively).

- A comparative analysis between the babies and adults showed trivial differences in overall average $\mathrm{PM}_{2.5}$ concentrations. Our results showed 5\% lower concentrations of $\mathrm{PM}_{2.5}$ for babies during morning drop-in hours as opposed to $10 \%$ higher concentrations during the afternoon pick-up hours compared with adults.

- A wide range of morphologies was observed under SEM, from exhaust agglomerates to mineral crustal forms and cloth fibres. Non-exhaust elements which are traces of brake abrasion were identified by means of EDS as well as mineral components from road dust re-suspension. Salting the roads might be an important source of $\mathrm{NaCl}$.

- The RDD rates imitated the trend of PMC. A considerable variability was observed

Cite this article as: Kumar, P., Rivas, I., Sachdeva, L., 2017. Exposure of in-pram babies to airborne particles during morning drop-in and afternoon pick-up of school children. Environment Pollution, doi:10.1016/j.envpol.2017.02.021 
between the hourly RDD estimated for female babies, which were between 1.2-11.6 $\mu \mathrm{g} \mathrm{h}^{-}$

${ }^{1}$ and 3.0-20.4 $\mu \mathrm{g} \mathrm{h}^{-1}$ during the morning and afternoon runs, respectively.

This study provides hitherto missing knowledge on the exposure of in-pram babies during the morning and afternoon pick-up periods of children from school. The findings clearly suggest much higher concentrations of fine PMC and PNC during the morning peak hours, especially on the traffic intersections and bus stand. While our exposure assessment and SEM/EDS analyses provided information on respiratory doses and various chemical species, further studies assessing the toxicity of particles in various size ranges are recommended to understand their impact on infant children.

\section{Acknowledgements}

This work has been carried out under the framework of the University Global Partnership Network (UGPN) funded project, NEST-SEAS (Next-Generation Environmental Sensing for Local To Global Scale Health Impact Assessment). The authors thank Zhenchun Yang, Simon Dai and Monirupa Ananya for their help during the data collection.

\section{References}

Agus, E.L.; Young, D.T.; Lingard, J.J.N.; Smalley, R.J.; Tate, E.J.; Goodman, P.S.; Tomlin, A.S. Factors influencing particle number concentrations, size distributions and modal parameters at a roof-level and roadside site in Leicester, UK. Science of the Total Environment 386:65-82; 2007

Ai, Z.T.; Mak, C.M. From street canyon microclimate to indoor environmental quality in naturally ventilated urban buildings: Issues and possibilities for improvement. Building and Environment 94:489-503; 2015

Al-Dabbous, A.N.; Kumar, P. Number and size distribution of airborne nanoparticles during summertime in Kuwait: First observations from the Middle East. Environmental Science \& Technology 48:13634-13643; 2014

Amato, F.; Pandolfi, M.; Escrig, A.; Querol, X.; Alastuey, A.; Pey, J.; Perez, N.; Hopke, P.K. Quantifying road dust resuspension in urban environment by Multilinear Engine: A comparison with PMF2. Atmospheric Environment 43:2770-2780; 2009a

Amato, F.; Pandolfi, M.; Viana, M.; Querol, X.; Alastuey, A.; Moreno, T. Spatial and chemical patterns of PM10 in road dust deposited in urban environment. Atmospheric Environment 43:1650-1659; 2009b

Amato, F.; Schaap, M.; Denier van der Gon, H.A.C.; Pandolfi, M.; Alastuey, A.; Keuken, M.; Querol, X. Effect of rain events on the mobility of road dust load in two Dutch and Spanish roads. Atmospheric Environment 62:352-358; 2012

Ashmore, M.R.; Dimitroulopoulou, C. Personal exposure of children to air pollution. Atmospheric Environment 43:128-141; 2009

Atkinson, R.W.; Mills, I.C.; Walton, H.; Anderson, H.R. Fine particle components and health-

Cite this article as: Kumar, P., Rivas, I., Sachdeva, L., 2017. Exposure of in-pram babies to airborne particles during morning drop-in and afternoon pick-up of school children. Environment Pollution, doi:10.1016/j.envpol.2017.02.021 
a systematic review and meta-analysis of epidemiological time series studies of daily mortality and hospital admissions. Journal of Exposure Analysis and Environmental Epidemiology 25:208-214; 2015

Azarmi, F.; Kumar, P. Ambient exposure to coarse and fine particle emissions from building demolition. Atmospheric Environment 137:62-79; 2016

Azarmi, F.; Kumar, P.; Mulheron, M.; Colaux, J.; Jeynes, C.; Adhami, S.; Watts, J. Physicochemical characteristics and occupational exposure to coarse, fine and ultrafine particles during building refurbishment activities. Journal of Nanopartcle Research 17: 343, doi: 10.1007/s11051-015-3141-z; 2015

Basagaña, X.; Esnaola, M.; Rivas, I.; Amato, F.; Alvarez-Pedrerol, M.; Forns, J.; LópezVicente, M.; Pujol, J.; Nieuwenhuijsen, M.; Querol, X.; Sunyer, J. Neurodevelopmental deceleration by urban fine particles from different emission sources: A longitudinal observational study. Environmental Health Perspective 124: 1630-1636, 2016

Bell, M.L. Assessment of the health impacts of particulate matter characteristics. Research report (Health Effects Institute) Boston, MA, 2012. Retrieved from http://wwwncbinlmnihgov/pubmed/22393584 (accessed 23.07.2016)

Bilenko, N.; Brunekreef, B.; Beelen, R.; Eeftens, M.; de Hoogh, K.; Hoek, G.; Koppelman, G.H.; Wang, M.; van Rossem, L.; Gehring, U. Associations between particulate matter composition and childhood blood pressure — The PIAMA study. Environment International 84:1-6; 2015

Buonanno, G.; Fuoco, F.C.; Morawska, L.; Stabile, L. Airborne particle concentrations at schools measured at different spatial scales. Atmospheric Environment 67:38-45; $2013 a$

Buonanno, G.; Stabile, L.; Morawska, L.; Russi, A. Children exposure assessment to ultrafine particles and black carbon: The role of transport and cooking activities. Atmospheric Environment 79:53-58; 2013b

Burtscher, H.; Schüepp, K. The occurrence of ultrafine particles in the specific environment of children. Paediatric Respiratory Reviews 13:89-94; 2012

Buzzard, N.A.; Clark, N.N.; Guffey, S.E. Investigation into pedestrian exposure to near-vehicle exhaust emissions. Environmental Health 8:1-13; 2009

Chithra, V.S.; Shiva Nagendra, S.M. Chemical and morphological characteristics of indoor and outdoor particulate matter in an urban environment. Atmospheric Environment 77:579$587 ; 2013$

Clark, N.A.; Demers, P.A.; Karr, C.J.; Koehoorn, M.; Lencar, C.; Tamburic, L.; Brauer, M. Effect of early life exposure to air pollution on development of childhood asthma. Environmental Health Perspective 118: 284-290, 2010

De Vizcaya-Ruiz, A.; Gutiérrez-Castillo, M.E.; Uribe-Ramirez, M.; Cebrián, M.E.; MugicaAlvarez, V.; Sepúlveda, J.; Froines, J. Characterization and in vitro biological effects of concentrated particulate matter from Mexico City. Atmospheric Environment 
40:S583-S592; 2006

Decan, N.; Wu, D.; Williams, A.; Bernatchez, S.; Johnston, M.; Hill, M.; Halappanavar, S. Characterization of in vitro genotoxic, cytotoxic and transcriptomic responses following exposures to amorphous silica of different sizes. Mutation Research - Genetic Toxicology and Environmental Mutagenesis 796:8-22; 2016

Deng, Q.; Lu, C.; Dan, N.; Bornehag, C. G.; Zhang, Y.; Liu, W.; Yuan, H.; Sundell, J. Early life exposure to ambient air pollution and childhood asthma in China. Environmental Research 143: 83-92; 2015

Deng, Q.; Lu, C.; Yu, Y.; Li, Y.; Sundell, J.; Norbäck, D. Early life exposure to traffic-related air pollution and allergic rhinitis in preschool children. Respiratory Medicine 121: 6773, 2016

Di Sabatino, S.; Kastner-Klein, P.; Berkowicz, R.; Britter, R.E.; Fedorovich, E. The modelling of turbulence from traffic in urban dispersion models - part I: theoretical considerations. Environmental Fluid Mechanics 3:129-143; 2003

Dons, E.; Int Panis, L.; Van Poppel, M.; Theunis, J.; Willems, H.; Torfs, R.; Wets, G. Impact of time-activity patterns on personal exposure to black carbon. Atmospheric Environment 45:3594-3602; 2011

Dylos. Dylos product description. Available from: http://wwwdylosproductscom/dc1700html (accessed 08092016); 2016

Galea, K.S.; Maccalman, L.; Amend-straif, M.; Gorman-Ng, M.; Cherrie, J.W. Are children in buggies exposed to higher $\mathrm{PM}_{2.5}$ concentrations than adults? Journal of Environmental Health Research 14:28-42; 2014

Garcia-Algar, O.; Canchucaja, L.; d'Orazzio, V.; Manich, A.; Joya, X.; Vall, O. Different exposure of infants and adults to ultrafine particles in the urban area of Barcelona. Environmental Monitoring \& Assessment 187:1-10; 2014

Garcia-Algar, O.; Canchucaja, L.; d'Orazzio, V.; Manich, A.; Joya, X.; Vall, O. Different exposure of infants and adults to ultrafine particles in the urban area of Barcelona. Environmental Monitoring \& Assessment 187, 4196, doi:10.1007/s10661-014-4196-5; 2015

Gidhagen, L.; Johansson, C.; Langner, J.; Foltescu, V.L. Urban scale modeling of particle number concentration in Stockholm. Atmospheric Environment 39:1711-1725; 2005

Goel, A.; Kumar, P. A review of fundamental drivers governing the emissions, dispersion and exposure to vehicle-emitted nanoparticles at signalised traffic intersections. Atmospheric Environment 97:316-331; 2014

Goel, A.; Kumar, P. Characterisation of nanoparticle emissions and exposure at traffic intersections through fast-response mobile and sequential measurements. Atmospheric Environment 107:374-390; 2015a

Goel, A.; Kumar, P. Zone of influence for particle number concentrations at signalised traffic

Cite this article as: Kumar, P., Rivas, I., Sachdeva, L., 2017. Exposure of in-pram babies to airborne particles during morning drop-in and afternoon pick-up of school children. Environment Pollution, doi:10.1016/j.envpol.2017.02.021 
intersections. Atmospheric Environment 123, Part A:25-38; 2015b

Goel, A.; Kumar, P. Vertical and horizontal variability in airborne nanoparticles and their exposure around signalised traffic intersections. Environtal Pollution 214:54-69; 2016

Goldman, L.R. Children - unique and vulnerable environmental risks facing children and recommendations for response. Environmental Health Perspective 103:13-18; 1995

Heal, M.R.; Kumar, P.; Harrison, R.M. Particles, air quality, policy and health. Chemical Society Reviews 41:6606-6630; 2012

Heinrich, J.; Slama, R. Fine particles, a major threat to children. International Journal of Hygiene and Environmental Health 210:617-622; 2007

Hinds, W.C. Aerosol technology: Properties, behaviour and measurement of airborne particles: John Wiley \& Sons, UK, pp. 483; 1999

ICRP. ICRP Publication 66: Human respiratory tract model for radiological protection A Report of a task group of the International Commission on Radiological Protection:1$482 ; 1994$

Kaur, S.; Nieuwenhuijsen, M.; Colvile, R. Personal exposure of street canyon intersection users to PM2.5, ultrafine particle counts and carbon monoxide in Central London, UK. Atmospheric Environment 39:3629-3641; 2005

Kim, K.H.; Sekiguchi, K.; Kudo, S.; Kinoshita, M.; Sakamoto, K. Carbonaceous and ionic components in ultrafine and fine particles at four sampling sites in the vicinity of roadway intersection. Atmospheric Environment 74:83-92; 2013

Kumar, P.; de Fatima Andrade, M.; Ynoue, R.Y.; Fornaro, A.; de Freitas, E.D.; Martins, J.; Martins, L.D.; Albuquerque, T.; Zhang, Y.; Morawska, L. New directions: From biofuels to wood stoves: The modern and ancient air quality challenges in the megacity of São Paulo. Atmospheric Environment 140:364-369; 2016

Kumar, P.; Fennell, P.; Britter, R. Effect of wind direction and speed on the dispersion of nucleation and accumulation mode particles in an urban street canyon. Science of the Total Environment 402:82-94; 2008a

Kumar, P.; Fennell, P.; Britter, R. Measurements of particles in the 5-1000 nm range close to road level in an urban street canyon. Science of the Total Environment 390:437-447; $2008 b$

Kumar, P.; Fennell, P.; Langley, D.; Britter, R. Pseudo-simultaneous measurements for the vertical variation of coarse, fine and ultra fine particles in an urban street canyon. Atmospheric Environment 42:4304-4319; 2008c

Kumar, P.; Goel, A. Concentration dynamics of coarse and fine particulate matter at and around the signalised traffic intersections. Environmental Science: Processes \& Impacts 18:1220-1235; 2016

Kumar, P.; Ketzel, M.; Vardoulakis, S.; Pirjola, L.; Britter, R. Dynamics and dispersion modelling of nanoparticles from road traffic in the urban atmospheric environment - a

Cite this article as: Kumar, P., Rivas, I., Sachdeva, L., 2017. Exposure of in-pram babies to airborne particles during morning drop-in and afternoon pick-up of school children. Environment Pollution, doi:10.1016/j.envpol.2017.02.021 
review. Journal of Aerosol Science 42:580-603; 2011

Kumar, P.; Khare, M.; Harrison, R.M.; Bloss, W.J.; Lewis, A.C.; Coe, H.; Morawska, L. New directions: Air pollution challenges for developing megacities like Delhi. Atmospheric Environment 122:657-661; 2015a

Kumar, P.; Morawska, L.; Birmili, W.; Paasonen, P.; Hu, M.; Kulmala, M.; Harrison, R.M.; Norford, L.; Britter, R. Ultrafine particles in cities. Environment International 66:1-10; 2014

Kumar, P.; Morawska, L.; Martani, C.; Biskos, G.; Neophytou, M.; Di Sabatino, S.; Bell, M.; Norford, L.; Britter, R. The rise of low cost sensing for managing air pollution in cities. Environment International 75:199-205; 2015b

Kumar, P.; Pirjola, L.; Ketzel, M.; Harrison, R.M. Nanoparticle emissions from 11 non-vehicle exhaust sources - a review. Atmospheric Environment 67:252-277; 2013

Kumar, P.; Robins, A.; Britter, R. Fast response measurements of the dispersion of nanoparticles in a vehicle wake and a street canyon. Atmospheric Environment 43:6110-6118; 2009

Landrigan, P.J.; Etzel, R.A. Textbook of children's Environmental Health. Oxford Uni- versity Press, New York; 2014

Longley, I.D.; Gallagher, M.W.; Dorsey, J.R.; Flynn, M.; Allan, J.D.; Alfarra, D.; Inglish, D. A case study of aerosol $(4.6 \mathrm{~nm}<\mathrm{Dp}<10 \mu \mathrm{m})$ number and mass size distribution measurements in a busy street canyon in Manchester, U.K. Atmospheric Environment 37:1563-1571; 2003

Mishra, V.K.; Kumar, P.; Van Poppel, M.; Bleux, N.; Frijns, E.; Reggente, M.; Berghmans, P.; Int Panis, L.; Samson, R. Wintertime spatio-temporal variation of ultrafine particles in a Belgian city. Sciencr of the Total Environment 431:307-313; 2012

Morawska, L.; Ristovski, Z.; Jayaratne, E.R.; Keogh, D.U.; Ling, X. Ambient nano and ultrafine particles from motor vehicle emissions: Characteristics, ambient processing and implications on human exposure. Atmospheric Environment 42:8113-8138; 2008

Moreno, T.; Martins, V.; Querol, X.; Jones, T.; BéruBé, K.; Minguillón, M.C.; Amato, F.; Capdevila, M.; de Miguel, E.; Centelles, S.; Gibbons, W. A new look at inhalable metalliferous airborne particles on rail subway platforms. Science of the Total Environment 505:367-375; 2015a

Moreno, T.; Reche, C.; Rivas, I.; Cruz Minguillón, M.; Martins, V.; Vargas, C.; Buonanno, G.; Parga, J.; Pandolfi, M.; Brines, M.; Ealo, M.; Sofia Fonseca, A.; Amato, F.; Sosa, G.; Capdevila, M.; de Miguel, E.; Querol, X.; Gibbons, W. Urban air quality comparison for bus, tram, subway and pedestrian commutes in Barcelona. Environmental Research 142:495-510; $2015 b$

Mouzourides, P.; Kumar, P.; Neophytou, M.K.A. Assessment of long-term measurements of particulate matter and gaseous pollutants in South-East Mediterranean. Atmospheric

Cite this article as: Kumar, P., Rivas, I., Sachdeva, L., 2017. Exposure of in-pram babies to airborne particles during morning drop-in and afternoon pick-up of school children. Environment Pollution, doi:10.1016/j.envpol.2017.02.021 
Environment 107:148-165; 2015

Northcross, A.L.; Edwards, R.J.; Johnson, M.A.; Wang, Z.-M.; Zhu, K.; Allen, T.; Smith, K.R. A low-cost particle counter as a realtime fine-particle mass monitor. Environmental Science: Processes \& Impacts 15:433-439; 2013

Nyhan, M.; McNabola, A.; Misstear, B. Comparison of particulate matter dose and acute heart rate variability response in cyclists, pedestrians, bus and train passengers. Science of the Total Environment 468-469:821-831; 2014

Omstedt, G.; Bringfelt, B.; Johansson, C. A model for vehicle-induced non-tailpipe emissions of particles along Swedish roads. Atmospheric Environment 39:6088-6097; 2005

Peled, R. Air pollution exposure: Who is at high risk? Atmospheric Environment 45:1781$1785 ; 2011$

Reche, C.; Querol, X.; Alastuey, A.; Viana, M.; Pey, J.; Moreno, T.; Rodríguez, S.; Y. González, Y.; Fernández-Camacho, R.; de la Rosa, J.; Dall'Osto, M.; Prévôt, A.S.H.; Hueglin, C.; Harrison, R.M.; Quincey, P. New considerations for PM, Black Carbon and particle number concentration for air quality monitoring across different European cities. Atmospheric Chemistry and Physics 11:6207-6227; 2011

Rivas, I.; Donaire-Gonzalez, D.; Bouso, L.; Esnaola, M.; Pandolfi, M.; de Castro, M.; Viana, M.; Àlvarez-Pedrerol, M.; Nieuwenhuijsen, M.; Alastuey, A.; Sunyer, J.; Querol, X. Spatiotemporally resolved black carbon concentration, schoolchildren's exposure and dose in Barcelona. Indoor Air 26:391-402; 2016

Rivas, I.; Kumar, P.; Hagen-Zanker, A. Exposure to air pollutants during commuting in London: are there inequalities among different socio-economic groups? Environment International, In Press, doi: 10.1016/j.envint.2017.01.019; 2017

Semple, S.; Apsley, A.; Maccalman, L. An inexpensive particle monitor for smoker behaviour modification in homes. Tobacco Control 22:295-298; 2013

Slezakova, K.; Pires, J.C.M.; Martins, F.G.; Pereira, M.C.; Alvim-Ferraz, M.C. Identification of tobacco smoke components in indoor breathable particles by SEM-EDS. Atmospheric Environment 45:863-872; 2011

Steinle, S.; Reis, S.; Sabel, C.E. Quantifying human exposure to air pollution--moving from static monitoring to spatio-temporally resolved personal exposure assessment. Science of the Total Environment 443:184-193; 2013

Steinle, S.; Reis, S.; Sabel, C.E.; Semple, S.; Twigg, M.M.; Braban, C.F.; Leeson, S.R.; Heal, M.R.; Harrison, D.; Lin, C.; Wu, H. Personal exposure monitoring of PM2.5 in indoor and outdoor microenvironments. Science of the Total Environment 508:383-394; 2015

Sunyer, J.; Esnaola, M.; Alvarez-pedrerol, M.; Forns, J.; Rivas, I.; Lopez-Vicente, M.; SuadesGonzalez, E.; Foraster, M.; Garcia-Esteban, R.; Basagaña, X.; Viana, M.; Cirach, M.; Moreno, T.; Alastuey, A.; Sebastian-Galles, N.; Nieuwenhuijsen, M.; Querol, X. Association between traffic-related air pollution in schools and cognitive development in primary school children : A prospective cohort study. PLoS Medicine 12, e1001792; 
2015

Thorpe, A.; Harrison, R.M. Sources and properties of non-exhaust particulate matter form road traffic: A review. Science of the Total Environment 400:270-282; 2008

US-EPA. Metabolically derived human ventilation rates: a revised approach based upon oxygen consumption rates. National Center for Environmental Assessment, Washington, DC; EPA/600/R-06/129F (accessed 02082016); 2009

Van Roosbroeck, S.; Jacobs, J.; Janssen, N.A.H.; Oldenwening, M.; Hoek, G.; Brunekreef, B. Long-term personal exposure to $\mathrm{PM}_{2.5}$, soot and NOx in children attending schools located near busy roads, a validation study. Atmospheric Environment 41:3381-3394; 2007

Van Roosbroeck, S.; Wichmann, J.; Janssen, N.A.H.; Hoek, G.; van Wijnen, J.H.; Lebret, E.; Brunekreef, B. Long-term personal exposure to traffic-related air pollution among school children, a validation study. Science of the Total Environment 368:565-573; 2006

Vardoulakis, S.; Gonzalez-Flesca, N.; Fisher, B.E.A. Assessment of traffic-related air pollution in two street canyons in Paris: implications for exposure studies. Atmospheric Environment 36:1025-1039; 2002

Viana, M.; Kuhlbusch, T.A.J.; Querol, X.; Alastuey, A.; Harrison, R.M.; Hopke, P.K.; Winiwarter, W.; Vallius, M.; Szidat, S.; Prévôt, A.S.H.; Hueglin, C.; Bloemen, H.; Wåhlin, P.; Vecchi, R.; Miranda, A.I.; Kasper-Giebl, A.; Maenhaut, W.; Hitzenberger, R. Source apportionment of particulate matter in Europe: A review of methods and results. Journal of Aerosol Science 39:827-849; 2008

von Bismarck-Osten, C.; Birmili, W.; Ketzel, M.; Massling, A.; Petäjä, T.; Weber, S. Characterization of parameters influencing the spatio-temporal variability of urban particle number size distributions in four European cities. Atmospheric Environment 77:415-429; 2013

Weber, S.; Kuttler, W.; Weber, K. Flow characteristics and particle mass and number concentration variability within a busy street canyon. Atmospheric Environment 40:7565-7578; 2006

Wehner, B.; Birmili, W.; Gnauk, T.; Wiedensohler, A. Particle number size distributions in a street canyon and their transformation into the urban air background: measurements and a simple model study. Atmospheric Environment 36:2215-2223; 2002

Wyzga, R.E.; Rohr, A.C. Long-term particulate matter exposure: Attributing health effects to individual PM components. Journal of the Air \& Waste Management Association 65:523-543; 2015

Zhu, Y.; Hinds, W.C.; Kim, S.; Shen, S.; Sioutas, C. Study of ultrafine particles near a major highway with heavy-duty diesel traffic. Atmospheric Environment 36:4323-4335; 2002

Cite this article as: Kumar, P., Rivas, I., Sachdeva, L., 2017. Exposure of in-pram babies to airborne particles during morning drop-in and afternoon pick-up of school children. Environment Pollution, doi:10.1016/j.envpol.2017.02.021 


\section{List of Tables}

Table 1. Review of studies that have assessed children/babies personal exposure of PM and UFP.

\begin{tabular}{|c|c|c|c|c|}
\hline City (Country) & Pollutants & Study design & Equipment Used & Author (year) \\
\hline Edinburgh (UK) & $\mathrm{PM}_{2.5}$ & $\begin{array}{l}\text { Measurements at adult } \\
\text { and buggy heights on } \\
3 \text { different routes; } 6 \\
\text { days, three 1-h } \\
\text { trips/day }\end{array}$ & $\begin{array}{l}\mathrm{PM}_{2.5}: \text { SidePak AM510 } \\
\text { (TSI Inc.) with } \text { PM }_{2.5} \\
\text { impactor }\end{array}$ & Galea et al., (2014) \\
\hline $\begin{array}{l}\text { Barcelona } \\
\text { (Spain) }\end{array}$ & $\begin{array}{l}\text { UFP }(20-1000 \\
n m)\end{array}$ & $\begin{array}{l}\text { Measurements at } \\
\text { buggy height }(0.55 \mathrm{~m}) \\
\text { and adult pedestrian } \\
(1.70 \mathrm{~m}) \text { on } 3 \text { different } \\
\text { walking routes of } 5 \\
\text { km. } 10 \text { days, total } \\
\text { measurements for } 20 \mathrm{~h}\end{array}$ & $\begin{array}{l}\text { UFP: P-TRAK } 8525 \text { (TSI } \\
\text { Inc.) }\end{array}$ & Garcia-Algar et al., (2014) \\
\hline Cassino (Italy) & $\begin{array}{l}\text { BC, UFP (10- } \\
300 \mathrm{~nm})\end{array}$ & $\begin{array}{l}103 \text { children }(8-11 \mathrm{yr}) \\
\text { once during } 48 \mathrm{~h}\end{array}$ & $\begin{array}{l}\text { UFP: NanoTracer (Philips) } \\
\text { BC: MicroAethalometer } \\
\text { AE51 (Magee Scientific) }\end{array}$ & Buonanno et al., (2013b) \\
\hline Switzerland & $\begin{array}{l}\text { UFP (10- } \\
700 \mathrm{~nm})\end{array}$ & $\begin{array}{l}\text { Child on a bicycle } \\
\text { with a child trailer } \\
\text { (measurements at } \\
\text { different heights) in } \\
\text { different routes }\end{array}$ & $\begin{array}{l}\text { UFP: DiSCmini (Matter } \\
\text { Aerosol) }\end{array}$ & $\begin{array}{l}\text { Burtscher and Schüepp } \\
\text { (2012) }\end{array}$ \\
\hline $\begin{array}{l}\text { Morgantown } \\
\text { (WV, USA) }\end{array}$ & $\begin{array}{l}\mathrm{PM} \text { (mass and } \\
\text { particle number } \\
\text { counts; } 1-1000 \\
\mathrm{~nm} \text { ), } \mathrm{CO}, \mathrm{CO}_{2} \\
\mathrm{NO}_{\mathrm{x}}\end{array}$ & $\begin{array}{l}\text { Measurements at } \\
\text { different heights near a } \\
\text { roadway }\end{array}$ & $\begin{array}{l}\text { UFP, } \mathrm{PM}_{1} \text { : Fast response } \\
\text { particle spectrometer } \\
(\mathrm{Cambustion} \text { DS500) } \\
\mathrm{CO} / \mathrm{CO}_{2}: \text { Horiba AIA-200 } \\
\mathrm{NO}_{\mathrm{x}}: \text { EcoPhysics CLD-822 }\end{array}$ & Buzzard et al., (2009) \\
\hline $\begin{array}{l}\text { Utrecht (The } \\
\text { Netherlands) }\end{array}$ & $\begin{array}{l}\mathrm{PM}_{2.5}, \text { Soot, } \\
\mathrm{NO}_{\mathrm{x}}, \mathrm{NO}_{2}\end{array}$ & $\begin{array}{l}54 \text { children }(10-12 \mathrm{yr}) \\
\text { monitored once during } \\
48 \mathrm{~h}\end{array}$ & $\begin{array}{l}\mathrm{PM}_{2.5} \text { GK2.05 cyclones } \\
\text { (BGI Inc., Waltham, MA) } \\
\mathrm{NO}_{\mathrm{x}} \text { : Ogawa passive } \\
\text { samplers (Ogawa and } \\
\text { Company USA, Inc.) }\end{array}$ & $\begin{array}{l}\text { Van Roosbroeck et al., } \\
\text { (2007) }\end{array}$ \\
\hline $\begin{array}{l}\text { Amsterdam } \\
\text { (The } \\
\text { Netherlands) }\end{array}$ & $\begin{array}{l}\mathrm{PM}_{2.5}, \text { Soot, } \\
\mathrm{NO}_{\mathrm{x}}, \mathrm{NO}, \mathrm{NO}_{2}\end{array}$ & $\begin{array}{l}14 \text { children }(9-12 \text { yr }) \\
\text { monitored } 4 \text {-times } \\
\text { during } 48 \text { h within } 2 \\
\text { months }\end{array}$ & $\begin{array}{l}\mathrm{PM}_{2.5} \text { : GK2.05 cyclones } \\
\text { (BGI Inc., Waltham, MA) } \\
\text { NO }_{\mathrm{x}} \text { : Ogawa passive } \\
\text { samplers (Ogawa and } \\
\text { Company USA, Inc.) }\end{array}$ & $\begin{array}{l}\text { Van Roosbroeck et al., } \\
\text { (2006) }\end{array}$ \\
\hline
\end{tabular}


Table 2. Summary of on-route PNC measurements at different TIs during morning and afternoon runs.

\begin{tabular}{crrrrrrrr}
\hline \multicolumn{7}{c}{ Morning } & \multicolumn{5}{c}{ Afternoon } \\
\hline $\begin{array}{c}\text { Section } \\
\begin{array}{c}\text { Rest } \\
\text { Route }\end{array}\end{array}$ & Average \pm SD & Median & Min & Max & Average \pm SD & Median & Min & Max \\
\hline TI all & $14908 \pm 8982$ & 12893 & 3997 & 34052 & $11031 \pm 6683$ & 8889 & 3721 & 33260 \\
\hline $\mathrm{TI}_{1}$ & $20062 \pm 13282$ & 15851 & 1762 & 53546 & $16455 \pm 12729$ & 11047 & 1706 & 50365 \\
\hline $\mathrm{TI}_{2}$ & $12058 \pm 7361$ & 9297 & 847 & 30998 & $9718 \pm 7154$ & 7518 & 1669 & 36356 \\
\hline $\mathrm{TI}_{3}$ & $13974 \pm 10574$ & 11448 & 675 & 41317 & $11251 \pm 10425$ & 8770 & 1677 & 53499 \\
\hline $\mathrm{TI}_{4}$ & $14223 \pm 14104$ & 8002 & 1377 & 54863 & $10784 \pm 7303$ & 9088 & 1739 & 28535 \\
\hline $\begin{array}{c}\text { Bus } \\
\text { Stand }\end{array}$ & $14396 \pm 9690$ & 11914 & 2043 & 49561 & $11534 \pm 6809$ & 9271 & 3019 & 24731 \\
\hline
\end{tabular}




\section{List of Figures}

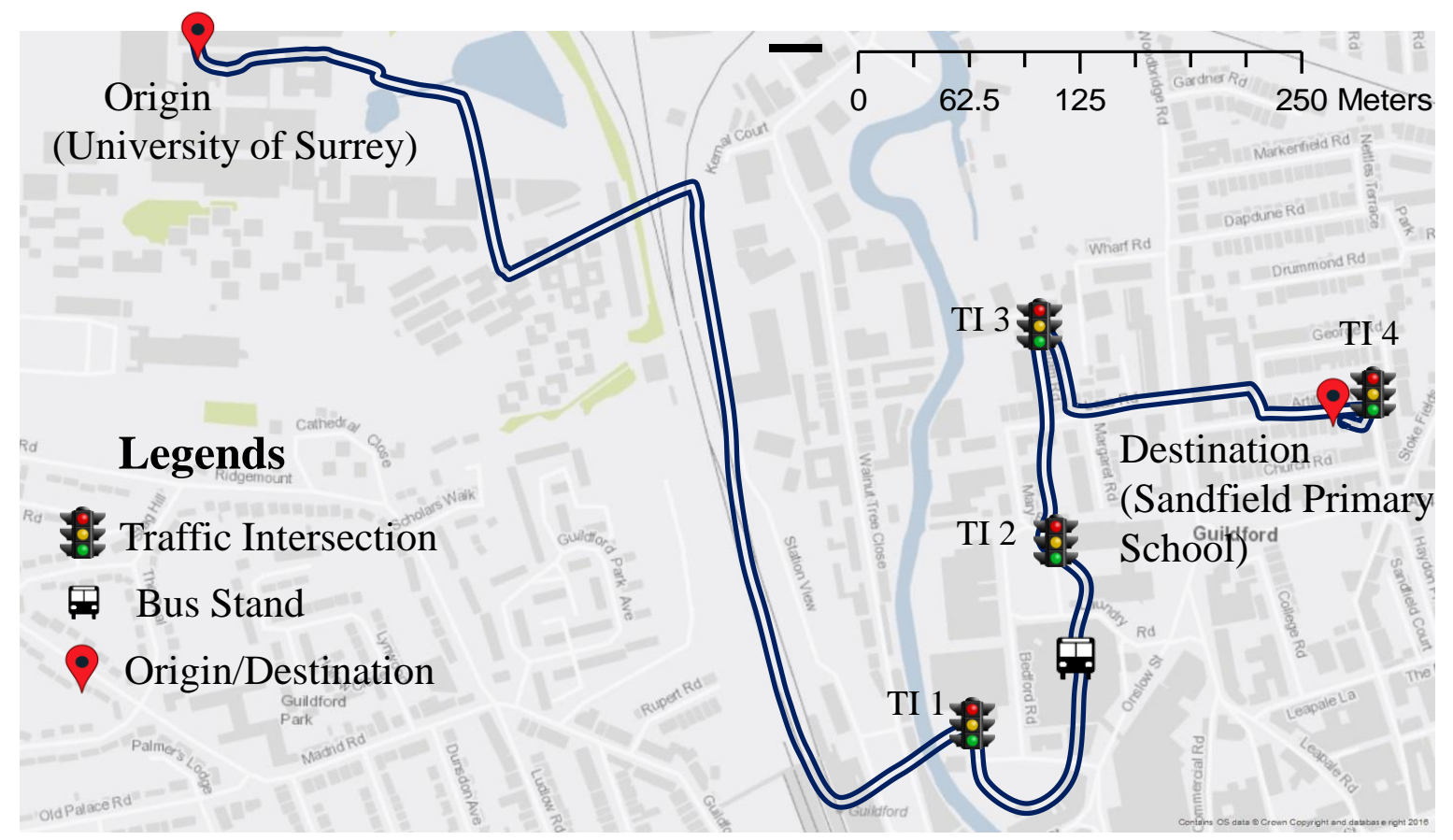

Figure 1. The map shows the route followed and indicates the location of the origin and destination points along with the bus stand and the traffic intersections crossed. 

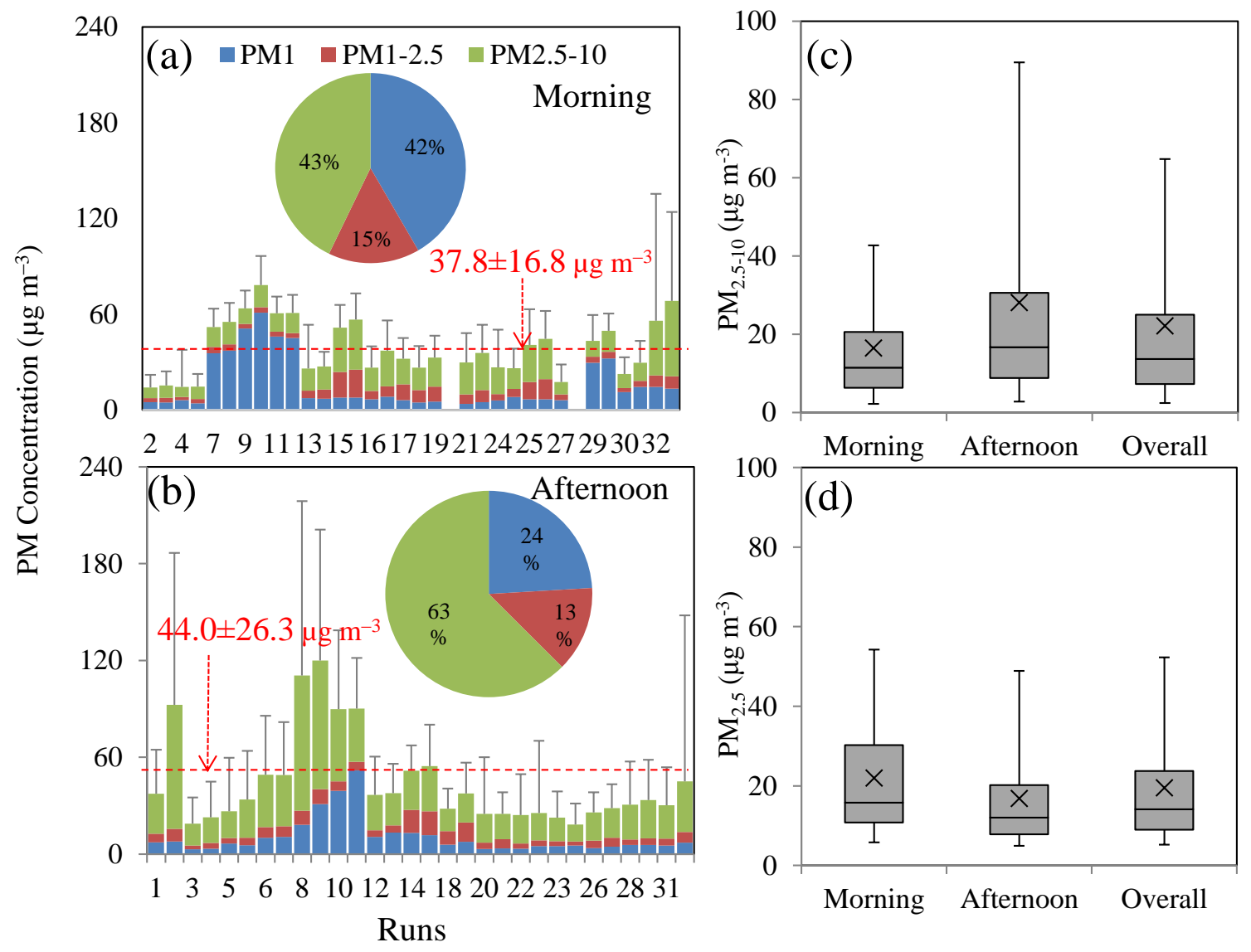

Figure 2. Concentrations of different PM types during (a) morning, (b) afternoon runs. The whiskers show the $5 \%$ and the $95 \%$ percentile while the cross sign shows the average value. In figures (a) and (b) each bar represents one-way trip between the origin (University of Surrey, UoS) and destination (Sandfield Primary School, SPS). Please note that each trip show two bars and the first and the second bars represent Up (UoS-SPS) and Down (SPS-UoS) trips, respectively. In figures (c) and (d), boxplots of $\mathrm{PM}_{2.5-10}$ and $\mathrm{PM}_{2.5}$ concentrations are shown for morning and afternoon runs; overall represent the average of both morning and afternoon runs. 


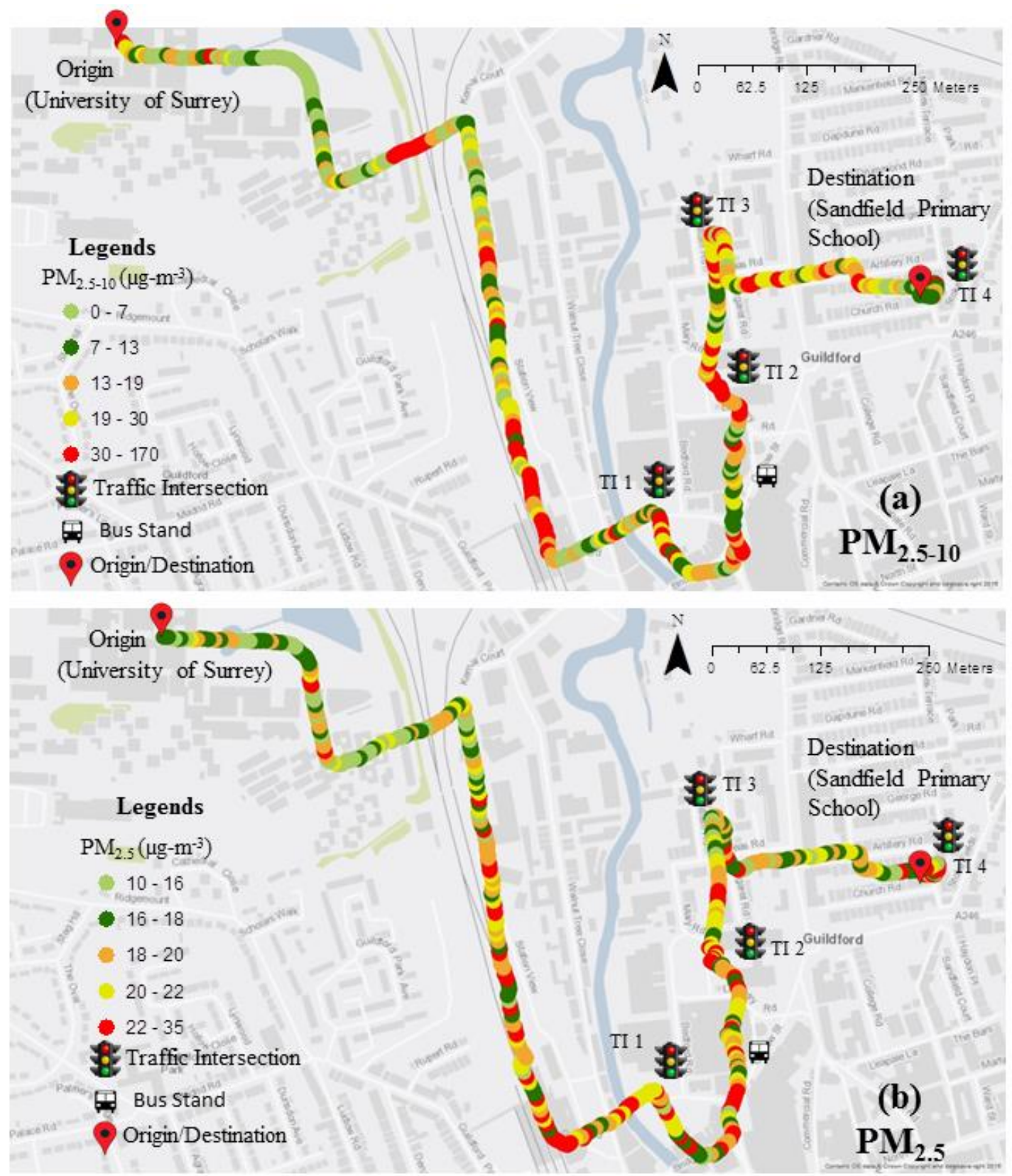

Figure 3. Spatial variability of (a) coarse particle concentration during run \#12 up, and (b) fine particles measured at the route during run \#25 down. The PMC range for each fraction was split into 5 colour categories by referring to the corresponding legend. 


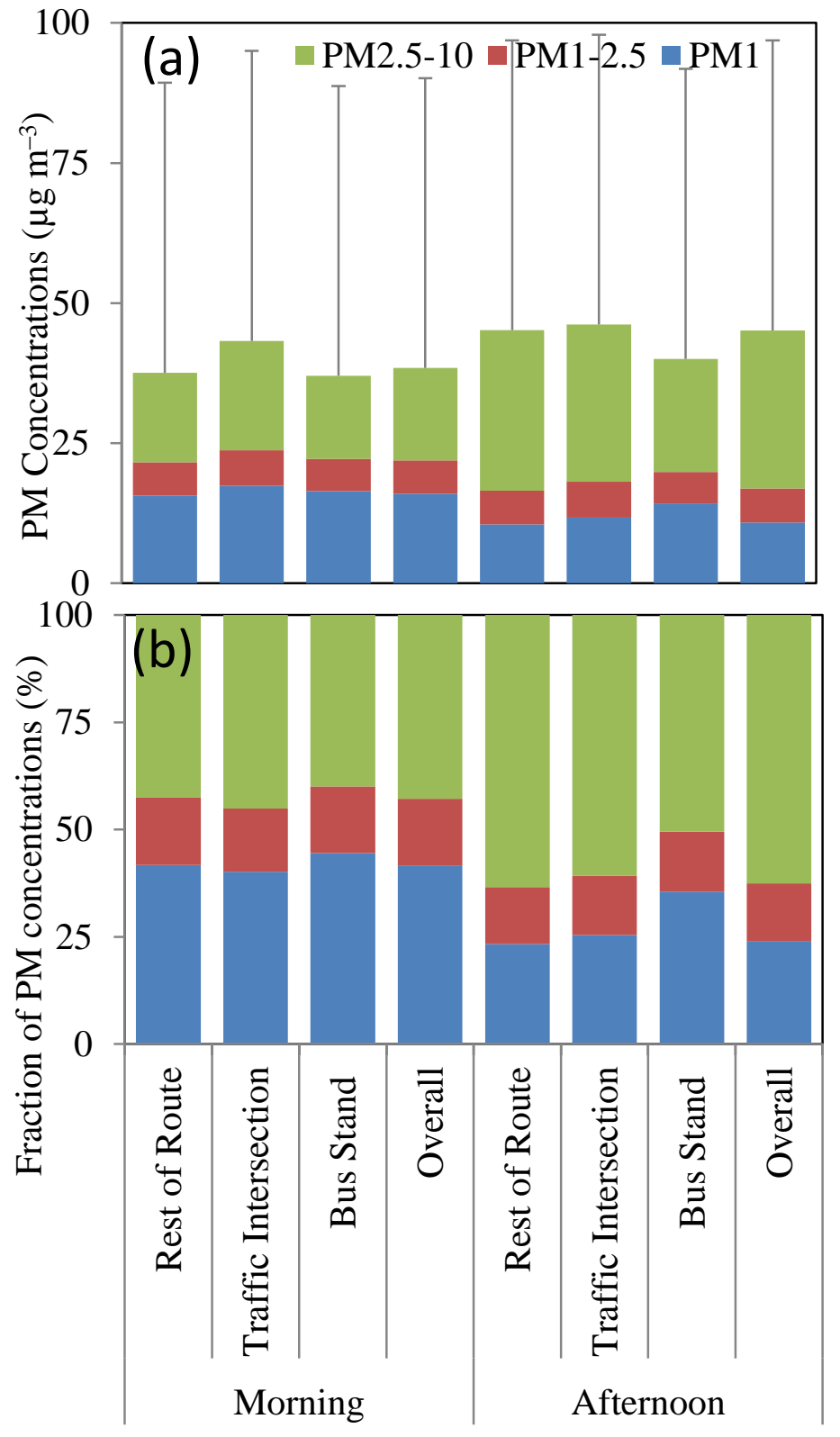

Figure 4. (a) PM concentrations and (b) their fractions during morning and afternoon runs at the traffic intersections, bus stand and the rest of the route. 


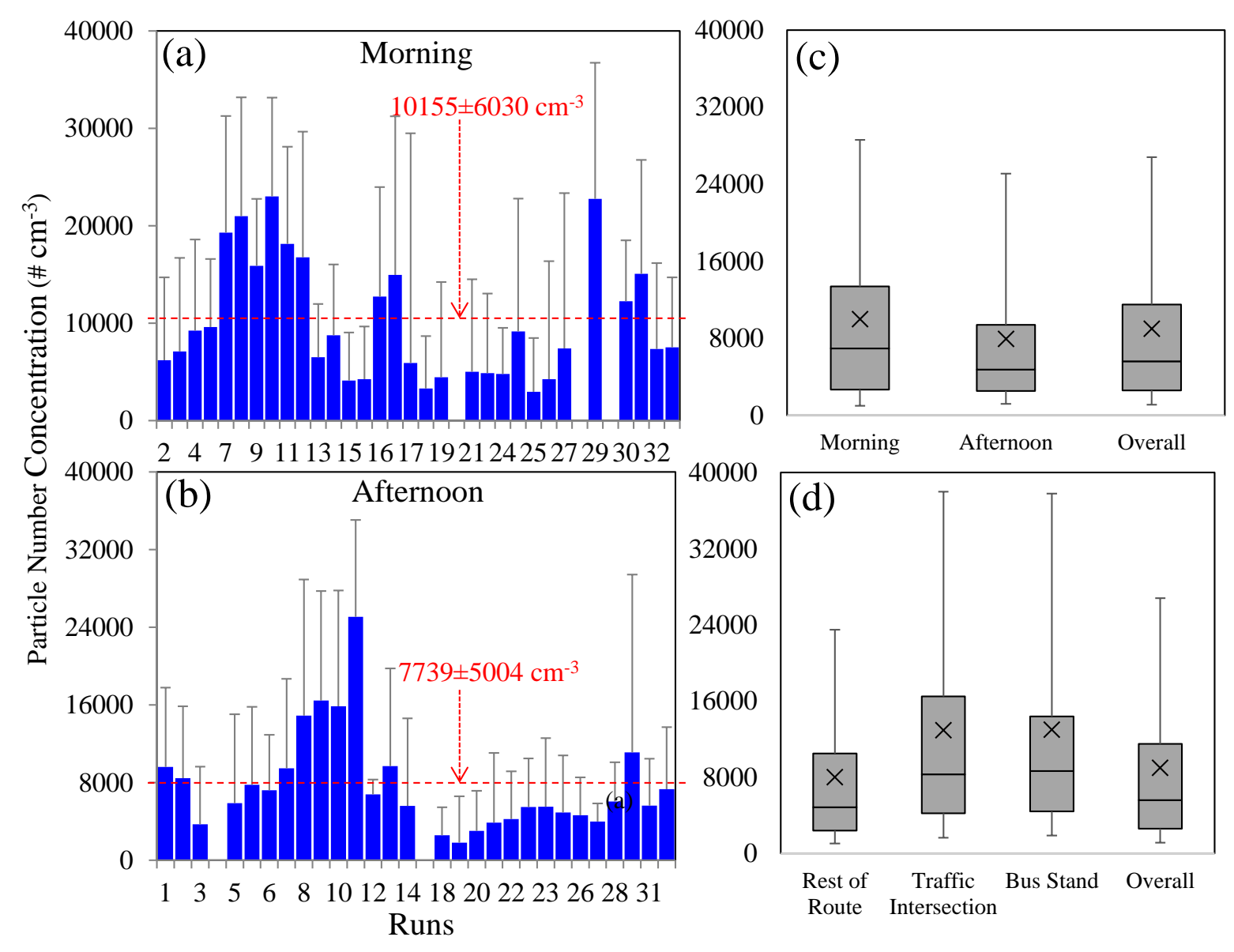

Figure 5. (a) Run wise concentrations of PNCs during (a) morning, (b) afternoon, (c) the averaged concentrations during morning and evening runs, (d) together with overall PNCs at different parts of the route. The whiskers show the $5 \%$ and the $95 \%$ percentile whereas the average values are shown by the cross signs. 


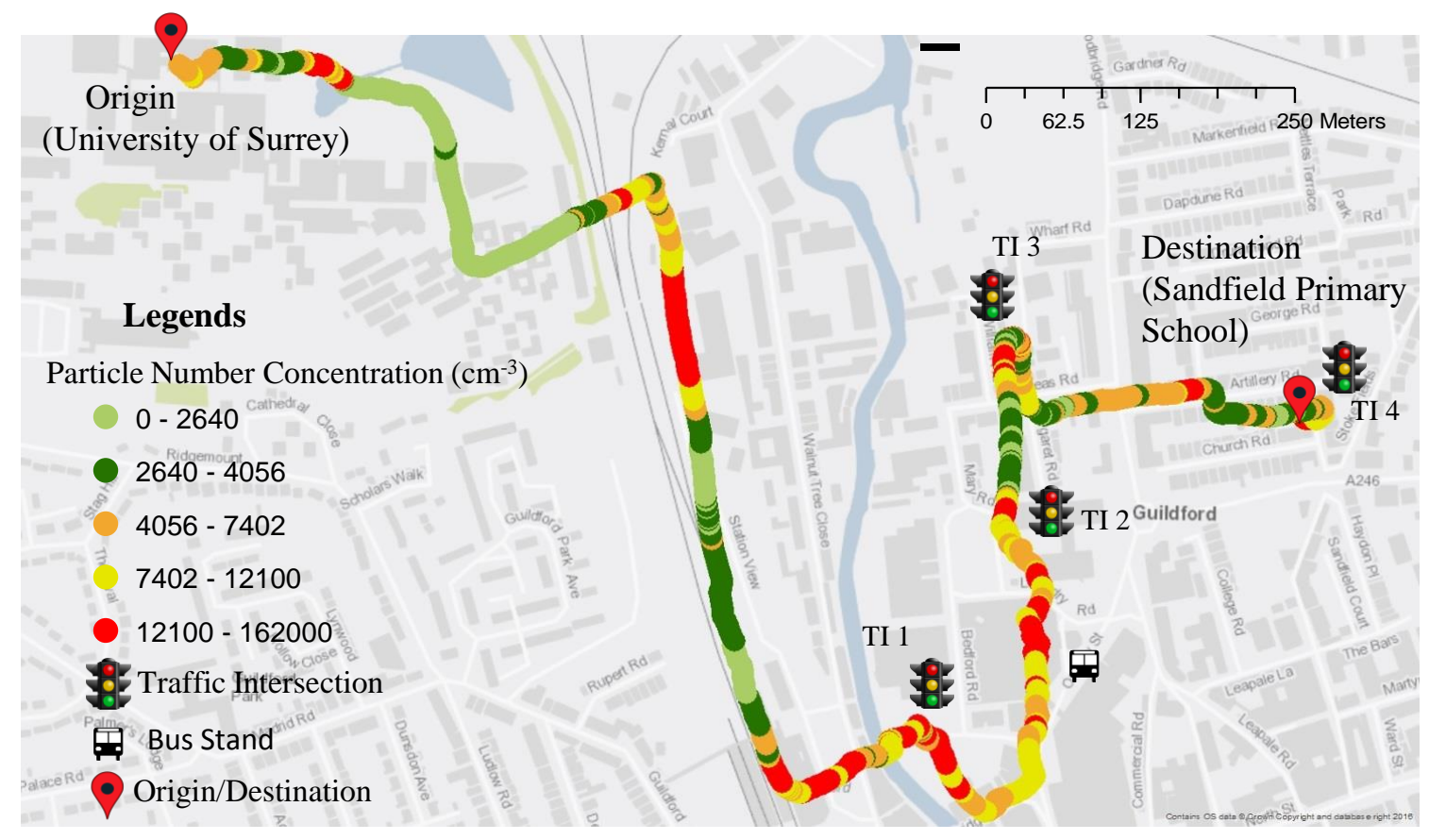

Figure 6. Spatial variability of ultrafine particles at the route. This GIS maps represent run \#24 down, which have average concentrations similar to the overall average of the entire runs. 

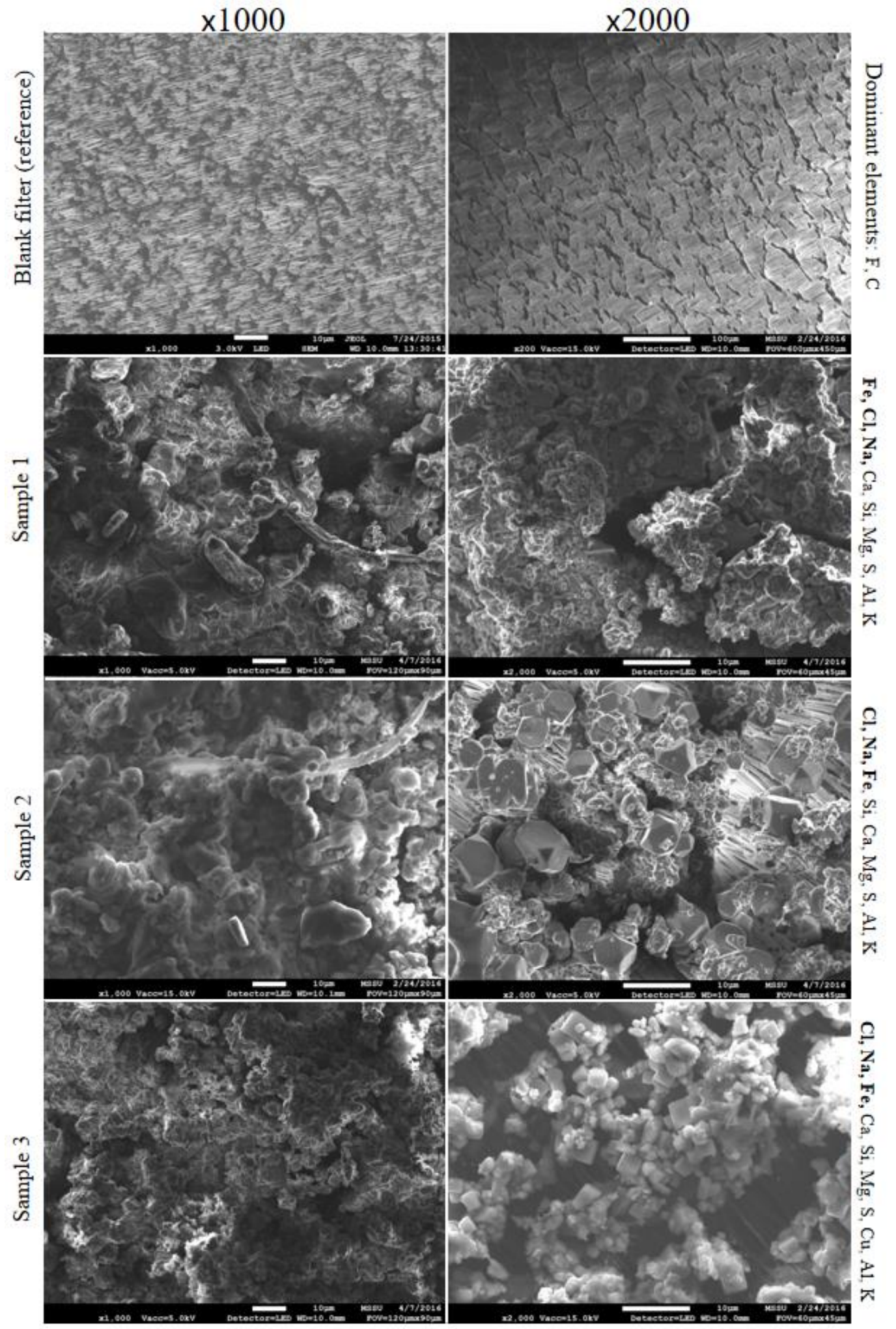

Figure 7. SEM images of the mass collected on the PTFE filters during the different runs.

Cite this article as: Kumar, P., Rivas, I., Sachdeva, L., 2017. Exposure of in-pram babies to airborne particles during morning drop-in and afternoon pick-up of school children. Environment Pollution, doi:10.1016/j.envpol.2017.02.021 


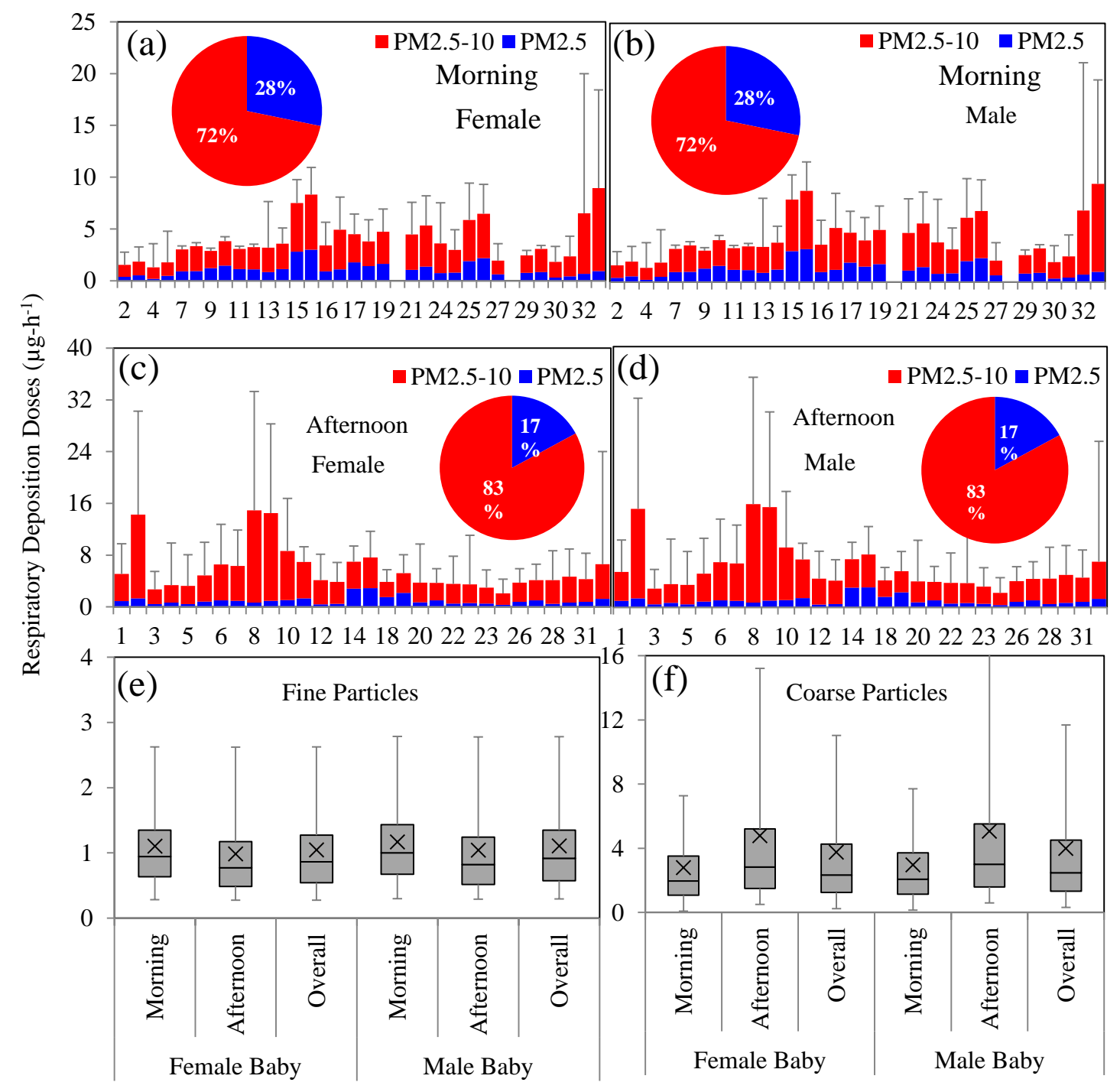

Figure 8. Respiratory deposition doses of in-pram babies during (a, b) morning, and (c, d) afternoon up and down runs. Please note that each run presents two bars for up and down measurements of the route, respectively. Each run numbers presents a return trip between the origin and destination points. The runs \#24 and \#29 did not show data because of the rain during these run periods. Sub-figure (e) and (f) show the RDD of fine and coarse particles, inside the baby pram during the morning and afternoon runs, respectively; overall represents the average of morning and afternoon runs. The whiskers show the 5\% and the $95 \%$ percentile whereas the average values are shown by the cross signs. 